Article

\title{
Emergy Based Decoupling Analysis of Ecosystem Services on Urbanization: A Case of Shanghai, China
}

\author{
Hengyu Pan ${ }^{1}$, Yong Geng ${ }^{2,3,4, *}$, Ji Han ${ }^{5,6, *} \mathbb{0}$, Cheng Huang ${ }^{7}$, Wenyi Han ${ }^{8}$ and Zhuang Miao ${ }^{9}$ \\ 1 Institute of Ecological and Environmental Science, Sichuan Agriculture University, Chengdu 611130, China; \\ Hengyu@sicau.edu.cn \\ 2 SJTU-UNIDO Joint Institute of Inclusive and Sustainable Industrial Development, School of International \\ and Public Affairs, Shanghai Jiao Tong University, Shanghai 200240, China \\ 3 China Institute of Urban Governance, Shanghai Jiao Tong University, Shanghai 200030, China \\ 4 School of Management, China University of Mining and Technology, No. 1 Daxue Road, \\ Xuzhou 221116, China \\ 5 Shanghai Key Lab for Urban Ecological Processes and Eco-Restoration, School of Ecological and \\ Environmental Sciences, East China Normal University, 500 Dongchuan Road, Shanghai 200241, China \\ 6 Institute of Eco-Chongming, 3663 N. Zhongshan Rd., Shanghai 200062, China \\ 7 School of Geographic Sciences, East China Normal University, 500 Dongchuan Road, \\ Shanghai 200241, China; hcheng@geo.ecnu.edu.cn \\ 8 Department of Geography, The University of Hong Kong, Pokfulam Road, Hong Kong, China; \\ vincehanwenyi@126.com \\ 9 Western China Economic Research Center, Southwestern University of Finance and Economics, \\ Chengdu 611130, China; miaozhuang@nuaa.edu.cn \\ * Correspondence: ygeng@sjtu.edu.cn (Y.G.); jhan@re.ecnu.edu.cn (J.H.); Tel.: +86-215-474-8019 (Y.G.)
}

Received: 19 October 2020; Accepted: 19 November 2020; Published: 23 November 2020

\begin{abstract}
In order to respond to rapid urbanization, understanding the relationships between urbanization and ecosystem services (ESs) is of practical importance to move toward sustainable urban development. In this study, an emergy-GIS based method is proposed to evaluate ESs. Spatiotemporal emergy values of water retention (WR), air purification (AP), carbon sequestration (CS), soil conservation (SC), and biodiversity conservation (BC) were quantified and relationships among these ESs were analyzed by taking China's largest city, Shanghai, as a case. The decoupling analysis was conducted to study the relationship between urbanization and ESs. Results show that the total value of regulating ESs had declined by $8.24 \%$ from 2005 to 2010. Chongming had the largest value of ESs, followed by Pudong. There is a synergetic relationship among AP, CS, and SC, while a tradeoff appears between WR and other services. Irregular " $U$ " shape relationships between the decrease of ESs and urbanization indicators were observed. Results from decoupling analysis show that ESs experienced weak decoupling from urbanization in most districts. Finally, policy implications were raised based on the study results.
\end{abstract}

Keywords: urbanization; ecosystem services; emergy accounting; decoupling analysis; Shanghai

\section{Introduction}

The world is experiencing unprecedented urban growth. According to a report from the United Nations [1], over 4 billion population lived in cities in 2015, accounting for $54 \%$ of the world's total population. Furthermore, it is projected that six out of 10 people will live in cities by 2030. The urbanization rate has risen more sharply in developing countries [2]. In China, accompanying with rapid economic growth since the reform and opening policies enacted in 1978, the urbanization rate increased from $17.92 \%$ in 1978 to $58.52 \%$ in 2017 , while the urban area had a 
significant increase from $9775 \mathrm{~km}^{2}$ in 1985 to $56,225 \mathrm{~km}^{2}$ in 2017 [3,4]. As the engine of economic growth, spurring domestic demand and catalyzing regional development [5], China's urbanization is expected to reach $80 \%$ in 2050 [6]. Although rapid urbanization boosted China's economic development, the huge increase in population density (36\% of the nation's land hosts $96 \%$ of the total population, especially in Eastern China [5]) and the tremendous change of land use (built-up area increased from 13,148 km² in 1990 to $40,058 \mathrm{~km}^{2}$ in 2010 [7]) has considerable impacts on ecosystems. The benefits people obtained from ecosystems, termed as ecosystem services (ESs), are essential for human survival [8]. In 1997, two seminal publications boosted the studies on ES [9,10]. In 2005, the Millennium Ecosystem Assessment (MA) further contributed to the great progress in this field. More recently, the increasing political interest in ES promoted national ES assessments worldwide, including the UK National Ecosystem Assessment (NEA), China's first national ecosystem assessment (2000-2010) [11], and Russia's National Ecosystem Assessment [12], etc., Urban ESs are the services directly produced by ecological structures within urban areas or peri-urban regions [13]. In order to address the challenges brought by rapid urbanization, it is critical to prepare more appropriate urban policies so that cities can become more inclusive, safe, resilient, and sustainable. This requires a holistic understanding of the relationship between urbanization and ESs so that the major challenges can be identified. It is also consistent with the sustainable development goal (SDG) 11 since 102 SDG targets are identified in relationship with urban ecosystems [14]. In 2012, the Chinese government adopted ecological civilization as the national development strategy, aiming to correct the GDP-based policy and guide economic and social development toward sustainable development, and strengthen ecosystem protection and governance. In particular, president $\mathrm{Xi}$ has decided to further pursue ecological civilization [15].

Academically, many studies have been conducted in this field. For example, Wan et al. [16] developed an urbanization indicator system and evaluated the urbanization process and the related ESs. They found that an irregular inverse " $U$ " relationship exists between urbanization and ESs in Huaibei, a mineral resource-based city in Anhui province. Su et al. [17] studied the response of ES changes to urbanization from 1994 to 2006 in Shanghai by using a geographically weighted regression (GWR) and proxy-based approach and identified significant spatial autocorrelation for the patterns of ESV changes. Zhou et al. [18] analyzed the relationship between urbanization and ESs in the Jing-jin-ji (JJ) urban agglomeration and found that increases in waterways, forests and orchards greatly offset the decrease of ESs caused by urban sprawl. Wang et al. [19] studied the relationship between ES and urbanization in the Beijing-Tianjin-Hebei (BTH) urban mega-region by employing a curve estimation method, in which urbanization is indicated by GDP density, population density, and the developed land proportion. Their results show that ESs and urbanization levels both increased. Lyu et al. [20] found that urbanization results in increased crop production, carbon storage, nutrient retention, and sand fixation in rural areas, but leads to decreased crop production, carbon storage, nutrient retention, and habitat quality in developing urban areas. Li et al. [21] demonstrated that urbanization in Nanjing has a spatially heterogeneous impact on ESs. Zhang et al. [22] adopted the bivariate Moran's I method to study the spatial correlations between ESs and urbanization in Wuhan, Their results show that there are negative spatial correlation between ESs and urbanization. Tian et al. [23] identified thresholds of ES response to the urbanization of the peri-urban area in Beijing by using a piecewise linear regression method. By adopting the Residential Environment Assessment Tool to value ecosystem services, Radford and James [24] found that the major ecosystem services exist at lower values within urban areas in the Greater Manchester region. Song and Deng [25] found a 34.66\% ecosystem service value loss from 1988 to 2008 due to the conversion from cultivated land to urban areas in the North China Plain. Delphin et al. [26] established urbanization scenarios in two disparate watersheds in Florida and found that the value of carbon storage and timber volume both decreased while the value of water yield increased. Sirakaya et al. [27] found that biodiversity restorations play a key role to provide ecosystem services in an urbanized world. Ferreira et al. [28] employed the benefit transfer method to quantify ecosystem service value and found that loss of arboreal vegetation caused by urbanization was the 
key factor of the ecosystem service value decline in the eco-tone area of Paraiba. Eigenbrod et al. [29] modeled the urban land-use change in Britain and predicted the related ecosystem services in 2031, in which their results demonstrated the significant losses of carbon sequestration and agricultural production under the urban sprawl growth scenario.

These studies demonstrate that the relationships between ESs and urbanization differ significantly due to the different urbanization modes and ESs quantification methods. In general, ESs assessment is the prerequisite for accurate analysis. There are two main approaches to assess ESs. The first is based on monetary valuations such as market price and willingness to pay, which captures the values of ESs anthropocentrically. Globally, Costanza et al. [9] estimated that the economic value of 17 global ecosystem services was US\$ 16-54 trillion per year in 1995 \$US. Later in 2014, they updated the economic value of global ecosystem services for the year 2011 to be $\$ 125$ trillion/yr [30]. However, such an economic approach is too narrow to capture the holistic picture of ESs [31]. The second is based on biophysical accounting (non-monetary). Many studies adopted the Integrated Valuation of Ecosystem Services and Tradeoffs models (InVEST) model to evaluate the biophysical values of ESs [11,32-35], while others employed the ecological modeling methods such as ecological footprint [36] and emergy accounting (EMA) [37,38]. Emergy is defined as "the available energy of one kind of previously used up directly and indirectly to make a service or product" [39]. Focusing on the role of the environment in support of human-dominated processes, EMA based studies quantify the natural ecosystem's contribution to produce ESs and identify the quality differences of different resource flows. In this regard, Pulselli et al. [40] analyzed the relationship between ESs and emergy flows and found that nature is more efficacious in producing ecosystem services than economic systems in producing GDP. Coscieme et al. [41] demonstrated that renewable emergy and ESs are strongly correlated within the national territory. Grönlund et al. [42] proposed two methods based on EMA to assess ESs, i.e., the natural driving forces and ecosystem function. Besides, EMA has been adopted to analyze ESs for various ecosystems, such as Maryland forests [43,44], subtropical forests and plantations restoration [45], Jing-Jin-Ji forest ecosystem [46], Erhai Lake [47], aquatic ecosystem [48] and mining systems [49]. Within urban systems, EMA has been integrated with GIS to study the spatiotemporal dynamics of land use, natural resources and ESs, including Campania Region [50], Abruzzo Region [51], the greater Taipei area [52], and Chongming Island [22].

These previous studies illustrate that the EMA method is a supply-side ESs evaluation method, which highlights the donor-side value of ESs and complements traditional economic assessment. However, few EMA based studies have been carried out to study the relationships between urbanization and ESs. To fill such a research gap, this study proposes an ESs accounting framework based on EMA and GIS. Decoupling analysis, introduced by OECD [53] and later improved by Tapio [54], was combined with a curve estimation method to characterize the relationships since the results are more applicable to communicate [55-58]. As one of the most urbanized cities in China and the world, Shanghai is taken as a case study city. Specifically, this study aims to answer the following questions:

What are the spatiotemporal dynamic changes of emergy values of ESs in Shanghai? What are the relationships among different ESs during the process of urbanization? What is the relationship between urbanization and ESs in Shanghai?

The paper is organized as follows. After this introduction section, Section 2 presents the city of Shanghai, related data sources, and research methods. Section 3 presents the research results and research limitations. Finally, Section 4 draws research conclusions and raises policy implications.

\section{Methods and Data}

\subsection{Case Study City and Data Sources}

Shanghai city is located in the easternmost region of the Yangtze River Delta. It is one of the most advanced and urbanized cities in China and the world. Figure 1 shows the location of Shanghai 
in China and its administrative districts. Shanghai occupies an area of $6340.5 \mathrm{~km}^{2}$ with a total population of 24.15 million in 2018. Its main geomorphic types include the western lacustrine plain, the eastern coastal plain, the central Huangpu River plain, and the estuarine delta [59,60]. Driven by rapid economic growth, Shanghai has experienced robust urbanization accompanied by various environmental challenges (Table 1). The Shanghai municipal government is ambitious to protect its local ecosystem. In February 2017, the Shanghai municipal government announced it will designate more than $40 \%$ of its land area as natural areas without any further development [32]. In November 2017, the State Council approved the Shanghai Master Plan for the period of 2017-2035, in which the forest coverage rate will increase from 15\% in 2015 to $23 \%$ in 2035 and the per capita green space will increase from $7.6 \mathrm{~m}^{2}$ in 2015 to $13 \mathrm{~m}^{2}$ in 2035. This ambitious goal demonstrates that Shanghai aims to move toward sustainable development.

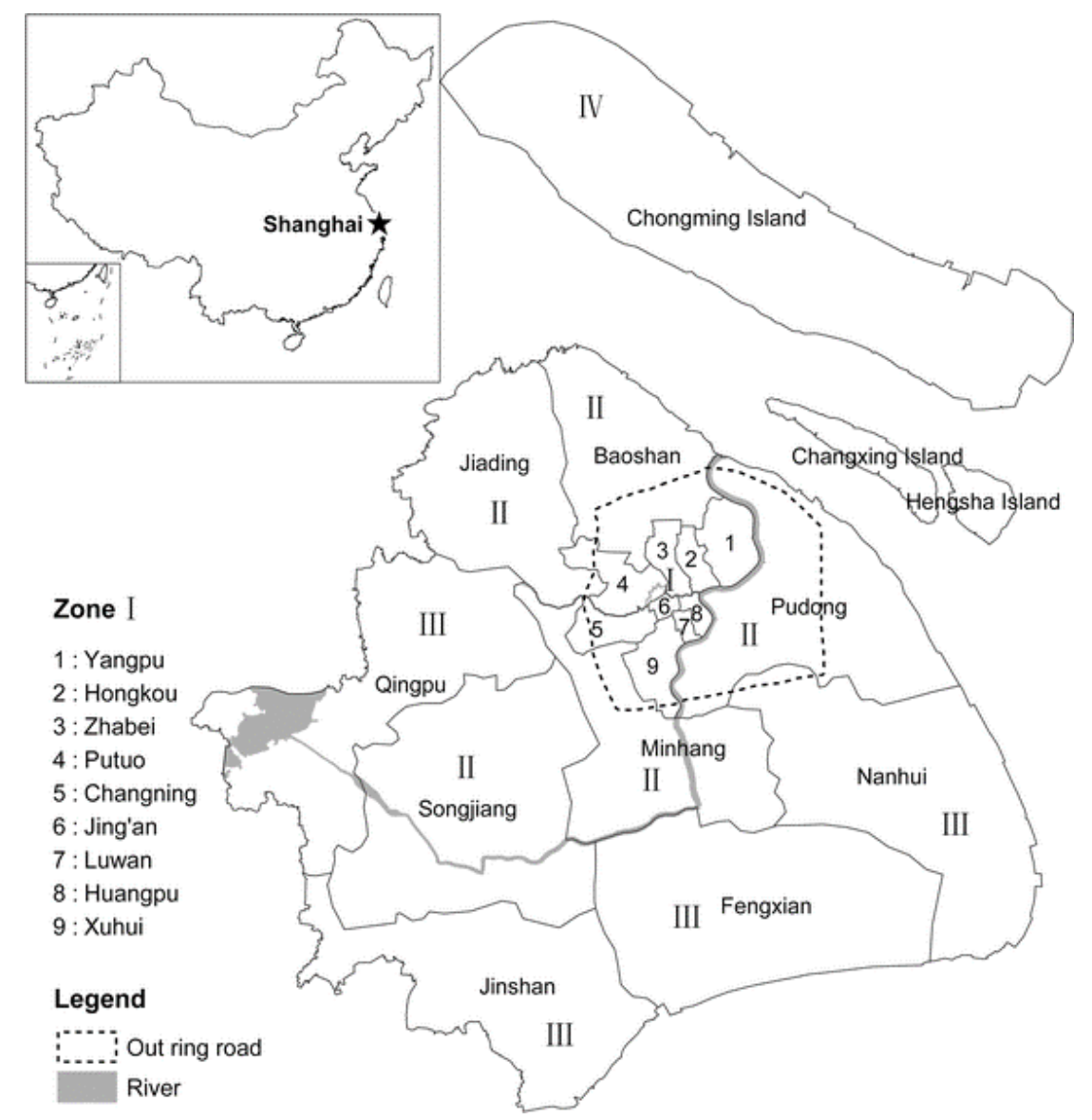

Figure 1. Location of Shanghai and the districts in China [61]. Note that Nanhui district was officially assigned to Pudong New Area on 9 August 2009. Huangpu district and Luwan district were abolished to establish the new Huangpu district in 2011. The State Council approved the withdrawal of Jing'an district and Zhabei district to build a new Jing'an district in November 2015.

Table 1. Urbanization indicators of Shanghai between 2005 and 2010 [62].

\begin{tabular}{cccccccc}
\hline Years & $\begin{array}{c}\text { Registered } \\
\text { Population } \\
\text { (Million) }\end{array}$ & $\begin{array}{c}\text { Migrant } \\
\text { Population } \\
\text { (Million) }\end{array}$ & $\begin{array}{c}\text { GDP (100 } \\
\text { Million } \\
\text { Yuan) }\end{array}$ & $\begin{array}{c}\text { Primary } \\
\text { Industry (100 } \\
\text { Million Yuan) }\end{array}$ & $\begin{array}{c}\text { Secondary } \\
\text { Industry (100 } \\
\text { Million Yuan) }\end{array}$ & $\begin{array}{c}\text { Tertiary } \\
\text { Industry (100 } \\
\text { Million Yuan) }\end{array}$ & $\begin{array}{c}\text { Buildup } \\
\text { Land (m } \mathbf{( m}^{\mathbf{2}} \text { ) }\end{array}$ \\
\hline 2005 & 13.60 & 4.38 & 9154.18 & 80.34 & 4452.92 & 4620.92 & $1.65 \times 10^{9}$ \\
2010 & 14.04 & 8.97 & $17,165.98$ & 114.15 & 7218.32 & 9833.51 & $2.01 \times 10^{9}$ \\
\hline
\end{tabular}




\subsection{Data Sources}

Given the interdisciplinary nature of this study, the required data should come from various sources, including governmental documents, statistical yearbooks, and research papers. Such data can be categorized into biophysical and socioeconomic types. The land cover data at a spatial resolution of $30 \mathrm{~m} \times 30 \mathrm{~m}$ were provided by the Data Center for Resources and Environmental Sciences at the Chinese Academy of Sciences (http://www.resdc.cn). Precipitation data, the net primary productivity (NPP), sunshine duration, and wind speed data, both at $1 \mathrm{~km} \times 1 \mathrm{~km}$ spatial resolution, were supplied by the National Earth System Science Data Sharing Infrastructure of China (http://www.geodata.cn). Evapotranspiration data at a spatial resolution of $1 \mathrm{~km} \times 1 \mathrm{~km}$ from MOD16A3 were supplied by NASA-USGA (http://files.ntsg.umt.edu/data/NTSG_Products/MOD16/). Social and economic data, including spatial distribution of population and GDP, both at $1 \mathrm{~km} \times 1 \mathrm{~km}$ spatial resolution, were obtained from the Data Center for Resources and Environmental Sciences, Chinese Academy of Sciences (http://www.resdc.cn). Runoff coefficients and species density (indigenous to China and endangered) were obtained from Ouyang et al. [11]. Data on ecosystem capacity to purify pollutants were from Wang et al. [19], Liu and Yang [63], and Zhang et al. [64]. Data of biomass in ecosystems were from Bai et al. [32]. Data related to soil conservation, including rainfall erosivity factors, soil erodibility factors, topographic factors, and cover-management factors, were from Teng [65]. The period of 2005-2010 was chosen as the study period due to data availability.

\subsection{Emergy-GIS Based Evaluation on ESs}

Emergy measures the contributions from both nature and humans to production based upon the environmental work required to support a system's dynamics [66]. By focusing on nature's investment, the complete role of the natural system as a source, sink, and regulator can be identified when conducting emergy analysis [67]. Unit Emergy Values (UEVs), which is the equivalent solar emergy (sej) input to generate a unit of output, convert all flows and stocks into emergy so that the distinctions between qualities of resources can be enabled. The total annual emergy input to the biosphere is defined as a geobiosphere emergy baseline (GEB). The updated $12.00 \times 10^{24} \mathrm{sej} / \mathrm{yr}$ value was adopted as the GEB for this study [66]. Integrating the GIS tool into emergy analysis can uncover the spatiotemporal dynamic changes of ESs. When adopting an emergy-GIS-based method to account for ESs, the following procedures should be taken.

\subsubsection{Identification of the Study Boundaries and Related ESs Provided by Local Ecosystems}

Since the purpose of this study is to evaluate urban ESs and analyze the relationship between urbanization and ESs, the boundary of this study is set as the administrative region of Shanghai city. The landscape was classified into 6 categories, including forest land, grassland, crop land, water area, buildup land, and unused land. Bai et al. [32] identified (1) water retention; (2) water purification; (3) carbon sequestration; (4) soil conservation, and; (5) biodiversity conservation as the priority ESs in Shanghai. Beyond these ESs, this study also takes air purification into consideration due to the severe ambient air pollution in Shanghai [68]. The related ESs provided by local ecosystems are referred to in Table 2.

\subsubsection{An Emergy-GIS-Based Framework to Evaluate Ecosystem Services}

An emergy flow diagram can reflect various flows and stocks of the studied system. Figure 2 shows the emergy flow diagram of Shanghai urban ESs. The renewable inputs, the role of the ecosystem and the urban system, and the main ecological processes among them are illustrated. After drawing this emergy flow diagram, the emergy based equations are raised to quantify ESs into emergy by considering the related ecological processes. The related UEVs and their sources in this study refer to Table A5 (Appendix A). Finally, the spatial emergy values of ESs are assigned and mapped by using GIS. 
Table 2. Land types and considered ecosystem services (ESs) in this study.

\begin{tabular}{|c|c|c|c|c|c|c|c|}
\hline & Ecosystem Services & Forest & Cropland & Grassland & Water & $\begin{array}{l}\text { Buildup } \\
\text { Land }\end{array}$ & $\begin{array}{c}\text { Unused } \\
\text { Land }\end{array}$ \\
\hline 1. & Water conservation & 1 & 1 & 1 & 1 & 1 & 1 \\
\hline 2. & Air, water and soil purification & 1 & 1 & 1 & 1 & & \\
\hline 3. & Carbon sequestration & 1 & 1 & 1 & & & \\
\hline 4. & Soil conservation & 1 & 1 & 1 & & 1 & 1 \\
\hline 5. & Biodiversity conservation & 1 & 1 & 1 & 1 & 1 & 1 \\
\hline
\end{tabular}

Note: The "1" in the table means ESs considered produced by different land-use types.

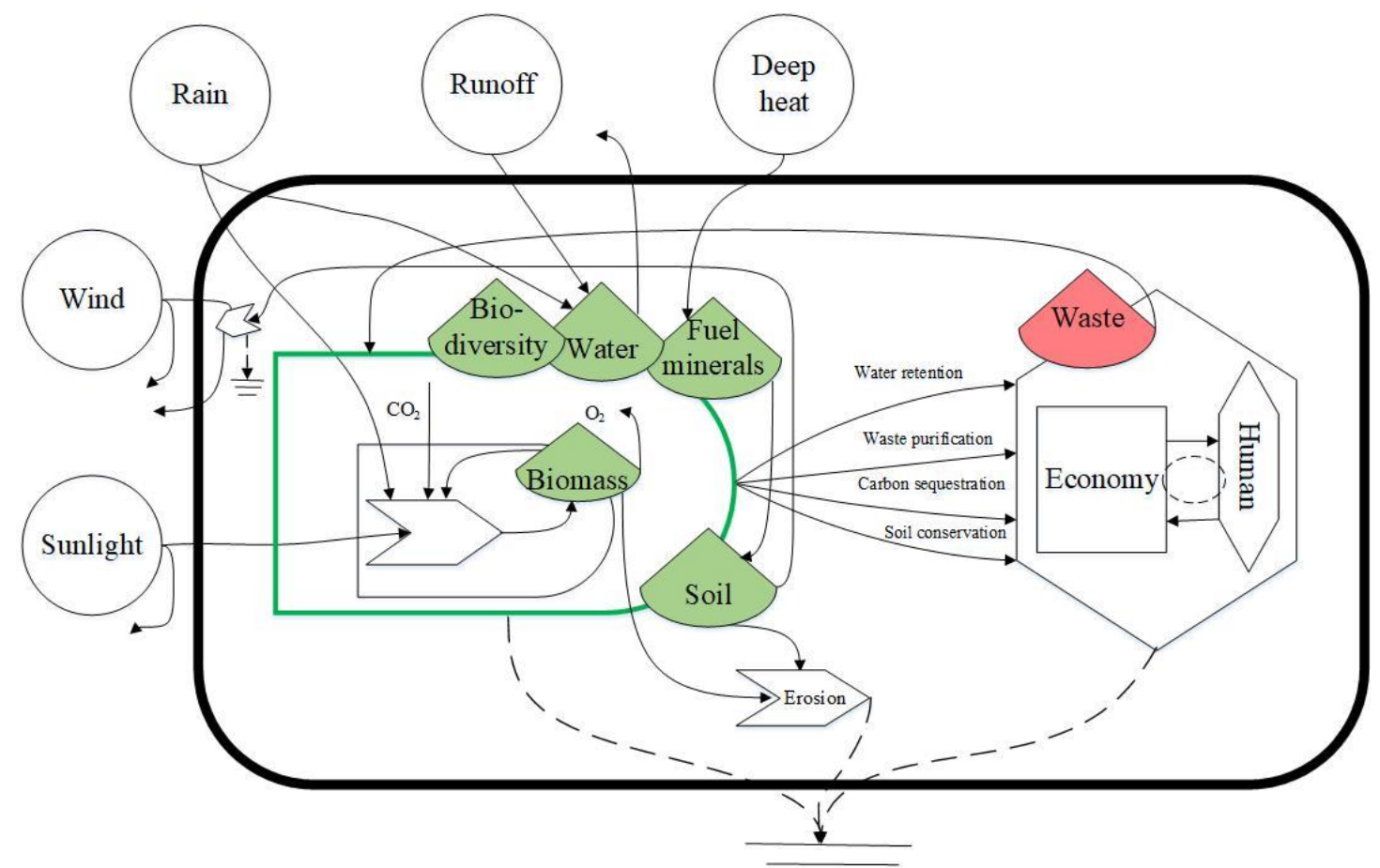

Figure 2. Emergy diagram of urban ecosystem services in this study.

(1) Water retention

Water retention refers to the ecosystem's ability to intercept or store water resources from natural precipitation [32]. It is crucial to keep an adequate freshwater supply in Shanghai so that local citizens can benefit. The equation proposed by Jia et al. [69] is adopted to account emergy of water retention service, as shown in Equation (1):

$$
E_{w r}=(P-E T) \times A \times U E V_{\text {water }}
$$

$E_{w r}$ is the emergy of water retention, $P$ is natural precipitation, $E T$ is local evapotranspiration, $A$ is the area of the ecosystem as defined by land cover, $U E V_{\text {water }}$ is the $U E V$ value of water.

(2) Air, water, and soil purification

Due to the purification ability of the local ecosystem, the adverse impacts of emissions on the environment and public health can be reduced. In this study, we adopt the accounting framework proposed by Yang et al. [46] to quantify these services. The reduced impacts (air, water, and soil purification services provided by urban ecosystems) are quantified by integrating Disability Adjusted Life Years $(D A L Y s)$ and Potentially Disappeared Fraction $(P D F)$ into emergy $[46,70,71]$. DALYs can be considered as a measurement of the gap between current health status and an ideal health situation 
where the entire population lives to an advanced age, free of disease and disability [72]. Potentially Disappeared Fraction (PDF) measures emissions' impacts on ecosystem quality which can be considered as the fraction of species with a high probability of no occurrence in a region due to unfavorable conditions $[46,73]$. The following equations quantify emissions' impacts into emergy.

$$
\begin{gathered}
E_{m H H}=\sum M_{i} \times D A L Y_{i} \times \tau_{H} \\
E_{m E Q}=\sum M_{i} \times P D F_{i} \times E_{B i o}=\sum M_{i} \times P D F_{i} \times M A X\left(R_{i}\right)
\end{gathered}
$$

$\operatorname{Max}\left(R_{i}\right)=\operatorname{Max}$ (Sum (sunlight, deep heat, tidal energy), wind energy, wave energy, rain (chemical potential energy), runoff (geopotential and chemical

potential energy))

$$
E_{m E}=E_{m H H}+E_{m E Q}
$$

where $E_{m H H}$ is the emergy required to reduce harmful effects on public health (sej); $M_{i}$ is the capacity of local ecosystem to purify the i-th pollutant ( $\mathrm{kg} / \mathrm{yr}$ ), Table A1 (See Appendix A) lists the detailed values of $M_{i} ; D A L Y_{i}$ is the disability-adjusted life year of one individual caused by $\mathrm{i}$-th air pollutant (cap yr $/ \mathrm{kg}$ ); $\tau_{H}$ is the per capita used emergy (sej/cap). $\tau_{H}$ in Shanghai equals to $2.30 \times 10^{16} \mathrm{sej} / \mathrm{capital}$ and $2.37 \times 10^{16} \mathrm{sej} / \mathrm{capital}$ in 2005 and 2010, respectively (recalculated from [60]). $E_{m E Q}$ is the emergy required to reduce emissions' impact on ecosystem quality (sej). $P D F_{i}$ indicates the potential fraction of species affected by the i-th emission ( $P D F \times$ ha $\times \mathrm{yr} \times \mathrm{kg}^{-1}$ ), Table A2 (Appendix A) lists the detailed values of $D A L Y$ and $P D F . E_{B i o}$ is the emergy of stored biological resource per unit area [49], which equals to $\operatorname{MAX}\left(R_{i}\right)$ [46]. $E_{m E}$ is the sum of $E_{m H H}$ and $E_{m E Q}$, which denotes the total emergy required to reduce all the emissions' impacts.

According to the State Forestry Administration of the People's Republic of China [74], water pollutant absorbed by local ecosystems can be calculated as follows:

$$
M_{w}=Q_{i} \times\left(c_{\text {input }, i}-c_{\text {output }, i}\right)
$$

where $M_{W}$ is the $\mathrm{i}$-th pollutant absorbed by water area $(\mathrm{kg} / \mathrm{yr}) ; Q_{i}$ is emission amount of pollutant $\mathrm{i}$ $(\mathrm{kg} / \mathrm{yr}) ; c_{\text {input }, i}$ is the concentration of pollutant $\mathrm{i}$ in water inlet $(\%)$ and $c_{\text {output }, i}$ is the concentration of pollutant $i$ in the water outlet (\%). This study ignores water pollutant purification services since the data related to water pollutant concentrations, including $D A L Y S$ and $P D F$ parameters, are lacking. Additionally, water quality monitoring is beyond the scope of this study.

\section{(3) Carbon sequestration}

In order to respond to global climate change, it is of great importance to increase the carbon sink. Especially, Shanghai is considered as the most vulnerable Chinese city facing climate change due to its low-lying character [32]. The following equations can account for carbon sequestration of ecosystems into emergy [46].

$$
\begin{gathered}
E_{m C S}=\sum 0.5 \times \frac{B_{i}}{T} \times A_{i} \times U E V_{b i o} \\
U E V_{b i o}=\frac{E_{m N P P} / S}{N P P}
\end{gathered}
$$

$E_{m N P P}=\operatorname{MAX}\left(R_{i}\right)=\operatorname{Max}$ (Sum (sunlight, deep heat, tidal energy), wind energy, wave energy, rain (chemical potential energy), runoff (geopotential and chemical potential energy))

where $E_{m C S}$ is the emergy of carbon sequestration, $B_{i}$ is the amount of biomass in ecosystem classified by landscape $i, T$ is the turnover time of biomass (one year estimated from Odum [39]), $A_{i}$ is the area 
of the related ecosystem of land use type i, $S$ is the area of the studied city. The amount of carbon sequestration is estimated as half of the biomass, and $U E V_{B i o}$ is the unit emergy value of biomass [46].

(4) Soil conservation

Soil erosion is a national dilemma in China. In particular, the Yangtze River Basin suffers the most [32]. Located in the Yangtze River Delta, Shanghai is also suffering from soil erosion. In this study, we assess the soil conservation service based on the Revised Universal Soil Loss Equation (RUSLE) [75], shown in Equations (10) and (11).

$$
\begin{gathered}
S C=R \times K \times L S \times(1-C \times P) \\
E_{S C}=S C \times U E V_{\text {soil }}
\end{gathered}
$$

where SC is the soil retention capacity $\left(t \mathrm{ha}^{-1} \mathrm{a}^{-1}\right), R$ represents the rainfall erosivity factor (MJ mm ha ${ }^{-1} \mathrm{~h}^{-1} \mathrm{a}^{-1}$ ), $K$ is the soil erodibility factor ( $\mathrm{t}$ ha $\mathrm{h} \mathrm{ha}^{-1} \mathrm{MJ}^{-1} \mathrm{~mm}^{-1}$ ), LS is the slope-length and steepness factor, $C$ is the cover-management factor, and $P$ is the conservation practices factor. Table A4 (See Appendix A) lists the values of these parameters. UEV soil is the UEV of soil.

\section{(5) Biodiversity conservation}

Maintaining biodiversity is crucial for the sustainable productivity of land due to its core role to provide ecosystem functions and services [76,77]. Equation (12) can account for the emergy required by biodiversity conservation [46].

$$
E_{b c}=N_{1} \times S \times(G E B \times T) / N_{0}
$$

where $E_{b c}$ represents the emergy required by biodiversity conservation (sej); $N_{1}$ is the species density in the study area (No./ha); $S$ is the area of the study system (ha); GEB is the geobiosphere emergy baseline (GEB) (sej/yr); $T$ is the average turnover time of species (yr) (3 million years); $N_{0}$ is the number of global species (8.7 million species [78]). Only the value of 2010 is considered in this study due to the lack of data for other years.

\subsection{Trade-Off and Synergy among ESs}

Studying the relationship among multiple ESs is of particular importance to identify win-win outcomes for ESs management [79]. Two interaction relationships of ESs have been identified, i.e., trade-off and synergy. Trade-off indicates that the provision of one ES is reduced as a result of another increased ES, while synergy reflects that multiple ESs are enhanced simultaneously [80]. This study quantifies the different values of ESs between 2005 and 2010 to investigate the relationships, i.e., $\mathrm{ES}_{\mathrm{i}, 2010}-\mathrm{ES}_{\mathrm{i}, 2005}$. Grid-scaled ESs data are extracted to conduct this calculation. Scatter diagrams are employed to demonstrate the relationships between two ESs. A point that appeared in the first or third quadrant indicates that the ESs are increased or decreased simultaneously, which can be classified as synergy. While a point that appears in the second or fourth quadrant, means that one ES is reduced as a result of another increased ES, which can be classified as trade-offs.

\subsection{Relationship between Urbanization Indicators and ESs}

Previous studies consider the total GDP of one city as the main indicator to reflect its urbanization level $[16,18,21,81]$. In this study, the GDP value of the manufacturing industry was adopted due to its great impact on regulating ESs. Other indicators, including population and the built-up land area, are also considered as key factors indicating urbanization. Since various relationships may exist between urbanization indicators and the total ESs, such as linear, logarithm, exponential, power law, and polynomial, the curve estimation method is adopted to determine the relationship [16,19]. We acknowledge that the regression analysis does not establish the causal relationship, but may uncover 
the dissimilarity or similarity relationship between the variables [43]. Thus, the Tapio decoupling method is employed to study the relationships between urbanization and ESs since it is more applicable to communicate [54]. The traditional Tapio decoupling theory focuses on the undesired output, such as $\mathrm{CO}_{2}$ and pollutants, while the ES is considered as the desired output in this study. Therefore, the decrease in ESs is adopted. Following Tapio [54], the urbanization elasticity of ESs can be calculated by using Equation (13). The district-level data were extracted to conduct this analysis.

$$
\text { Urbanization elasticity of ESs }=\frac{\% \triangle T E S}{\% \Delta U I}
$$

where $\triangle T E S$ is the decreased value of the total ES during the study period; $\triangle U I$ refers to the changed value of corresponding urbanization indicators, i.e., population, the built-up land, and the GDP of manufacturing industry during the study period. Finally, the degrees of coupling and decoupling of ES influenced by urbanization can be identified according to Figure 3.

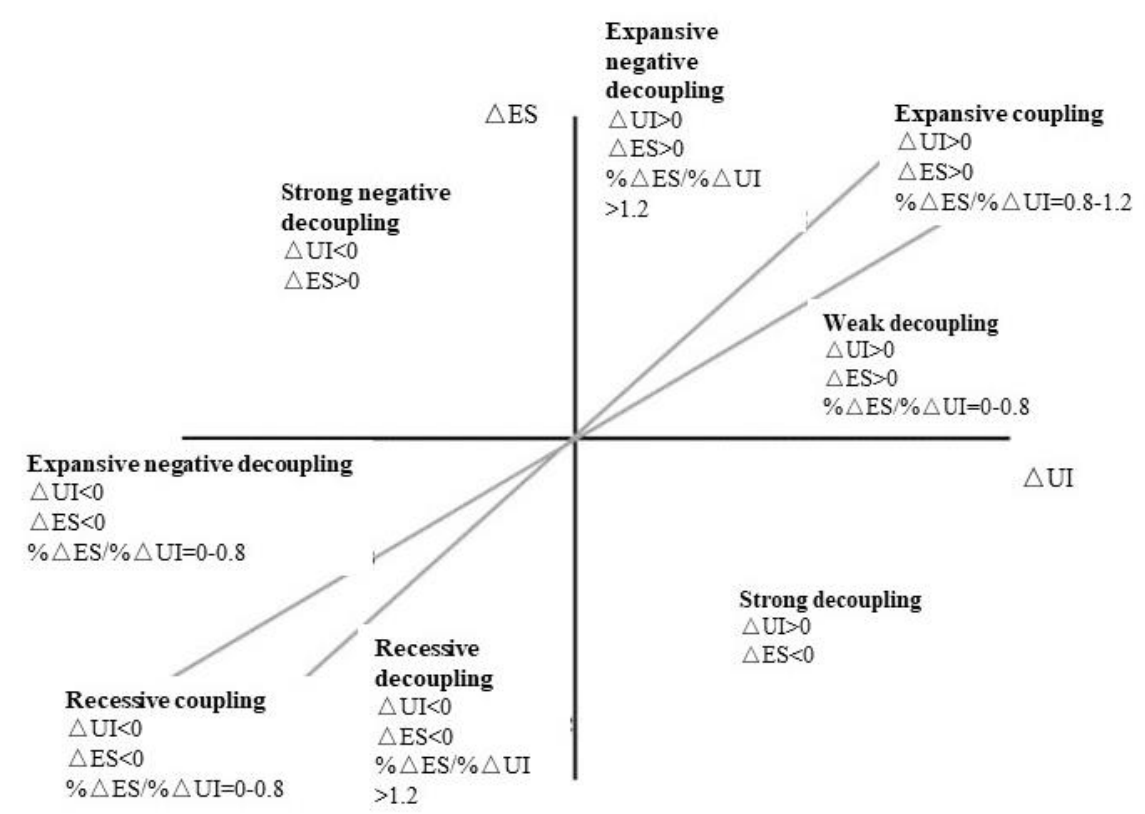

Figure 3. The degrees of coupling and decoupling of ESs from urbanization (modified from [54]).

\section{Results}

\subsection{Dynamic Changes and Spatial Pattern of Land Use and ESs}

Table 3 shows the changes in land use and land cover (LULC) in Shanghai. During the study period, crop land accounted for the largest proportion, followed by built-up land and water area. During the study period, the area of crop land had decreased by $10.26 \%$ from $4.19 \times 10^{9} \mathrm{~m}^{2}$ in 2005 to $3.76 \times 10^{9} \mathrm{~m}^{2}$ in 2010 , while the area of unused land and built-up land had increased by $36.88 \%$ and $21.72 \%$, respectively. Forest land increased by $4.31 \%$ from $1.12 \times 10^{8} \mathrm{~m}^{2}$ in 2005 to $1.17 \times 10^{8} \mathrm{~m}^{2}$ in 2010. This indicates that the large increases in unused land and built-up land are mainly at the cost of decreased crop land. Figure 4 shows the LULC at the district level, and Figure 5 illustrates the contributions from main districts to land-use changes. For all districts, both built-up land and unused land increased or remained unchanged. Pudong had the most significant change in land use, which contributed $116.68 \%$ of total forest land increase, $33.12 \%$ of total crop land decrease, $29.95 \%$ of total buildup land increase, and $43.04 \%$ of the total unused land increase. 
Table 3. Land-use change in Shanghai from 2005 to $2010\left(\mathrm{~m}^{2}\right)$.

\begin{tabular}{cccc}
\hline Land Use Types & Area in 2005 & Area in 2010 & Change Rate (\%) \\
\hline Forest land & $1.12 \times 10^{8}$ & $1.17 \times 10^{8}$ & $4.31 \%$ \\
Grassland & $9.74 \times 10^{6}$ & $9.74 \times 10^{6}$ & $0.00 \%$ \\
Crop land & $4.19 \times 10^{9}$ & $3.76 \times 10^{9}$ & $-10.26 \%$ \\
Buildup Land & $1.65 \times 10^{9}$ & $2.01 \times 10^{9}$ & $21.72 \%$ \\
Water area & $1.95 \times 10^{8}$ & $1.95 \times 10^{8}$ & $0.00 \%$ \\
Unused land & $1.85 \times 10^{8}$ & $2.53 \times 10^{8}$ & $36.88 \%$ \\
\hline
\end{tabular}

A

\section{LULC-2005}

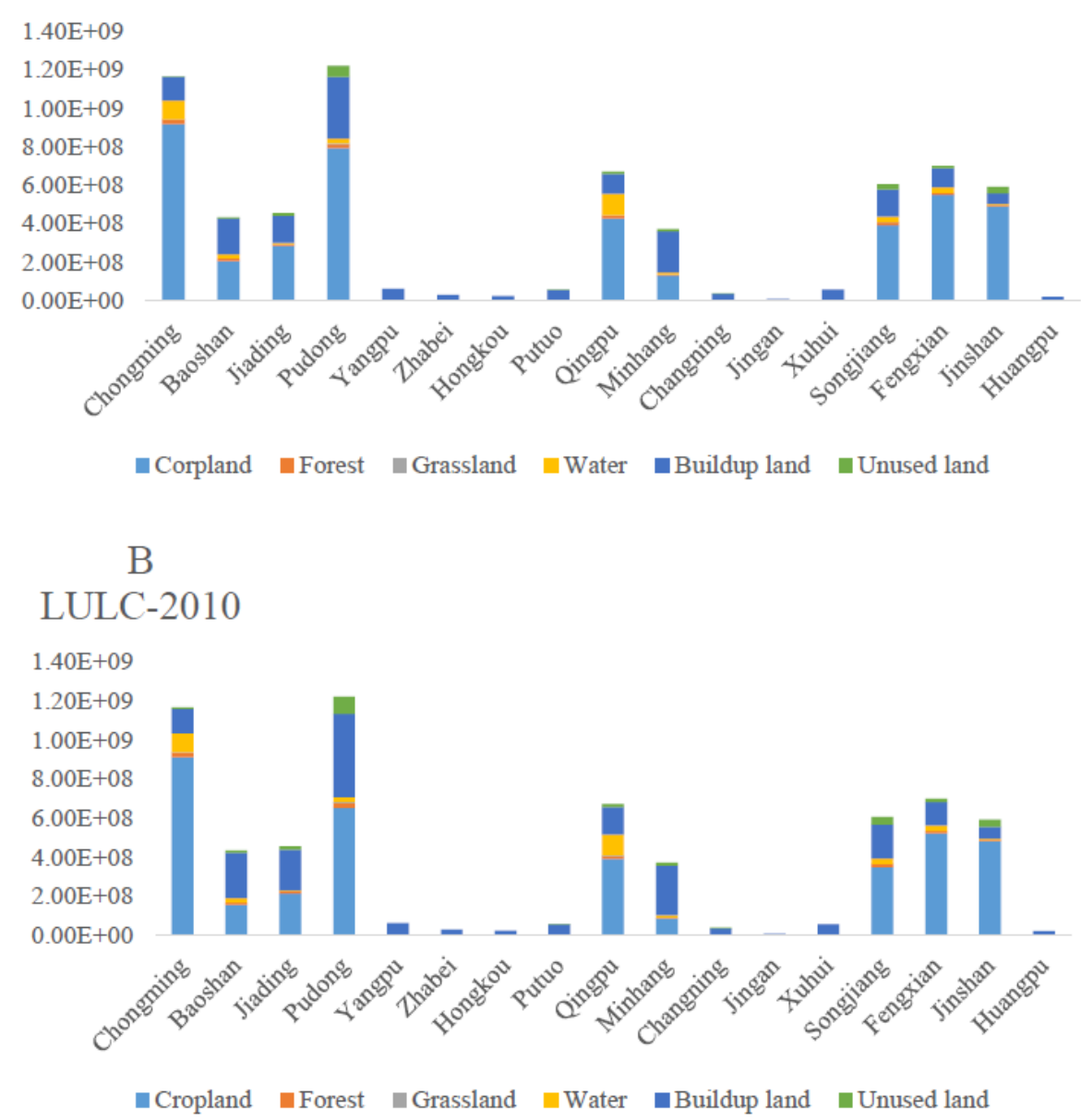

Figure 4. Land use and Land cover (LULC) at district-level. (A): LULC in 2005, (B): LULC in 2010. 


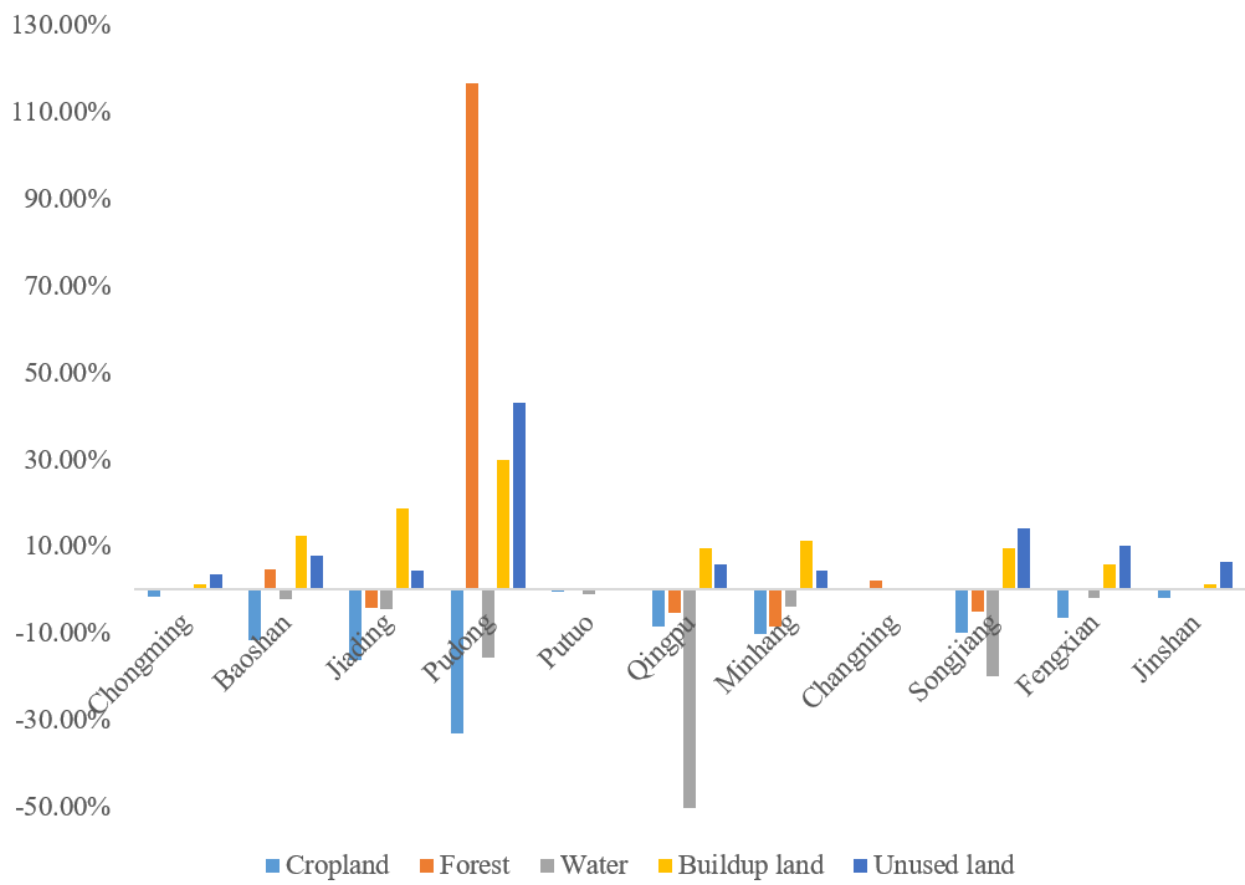

Figure 5. Contributions from main districts to land-use change.

Jiading had the second-largest decrease in crop land and increase in built-up land, accounting for $16.24 \%$ of total crop land decrease and $18.66 \%$ of total built-up land increase, respectively. The largest decrease in forest land occurred in Minhang, which contributed $8.63 \%$ of the total forest land decrease. Finally, the maximum water area reduction occurred in Qingpu.

Spatial distributions and changes of the considered ESs are shown in Figures 6-10. Spatial values of ESs at the district level were illustrated in Figure 11. For AP, Chongming had the largest contribution, accounting for $21.70 \%$ and $23.74 \%$ of the total AP in 2005 and 2010, respectively, followed by Pudong and Fengxian. Regarding CS, Chongming had also the largest contribution, accounting for $21.14 \%$ and $21.74 \%$ of the total in 2005 and 2010, respectively, followed by Pudong and Fengxian. Pudong contributed $19.16 \%$ and $18.67 \%$ to the total SC in 2005 and 2010, respectively, followed by Chongming and Fengxian. In 2010, Chongming had the highest emergy value of biodiversity, with a figure of $3.14 \times 10^{30}$ sej, followed by Pudong and Jinshan. When considering the total regulating ESs as a whole, Chongming had the highest value of ESs, with figures of $7.03 \times 10^{19}$ sej in 2005 and $6.87 \times 10^{19}$ sej in 2010, followed by Pudong $\left(6.67 \times 10^{19}\right.$ sej in 2005 and $5.86 \times 10^{19}$ sej in 2010), Fengxian $\left(4.21 \times 10^{19}\right.$ sej in 2005 and $3.99 \times 10^{19}$ sej in 2010), Jinshan $\left(3.62 \times 10^{19}\right.$ sej in 2005 and $3.51 \times 10^{19}$ sej in 2010), Qingpu (3.46 $\times 10^{19}$ sej in 2005 and $3.21 \times 10^{19}$ in 2010), and Songjiang $\left(3.24 \times 10^{19}\right.$ sej in 2005 and $2.95 \times 10^{19}$ sej in 2010). Total ESs in all the districts had decreased or remained unchanged. For instance, total ESs in Minhang, Jiading, Baoshan and Pudong had decreased by $18.17 \%, 16.78 \%, 14.74 \%$ and $12.26 \%$ during 2005-2010, respectively. Finally, Pudong contributed $35.31 \%, 28.78 \%$, and $19.54 \%$ of the total-decrease of SC, AP, and WR, respectively. Jiading had the largest contribution to CS decrease, followed by Minhang. 


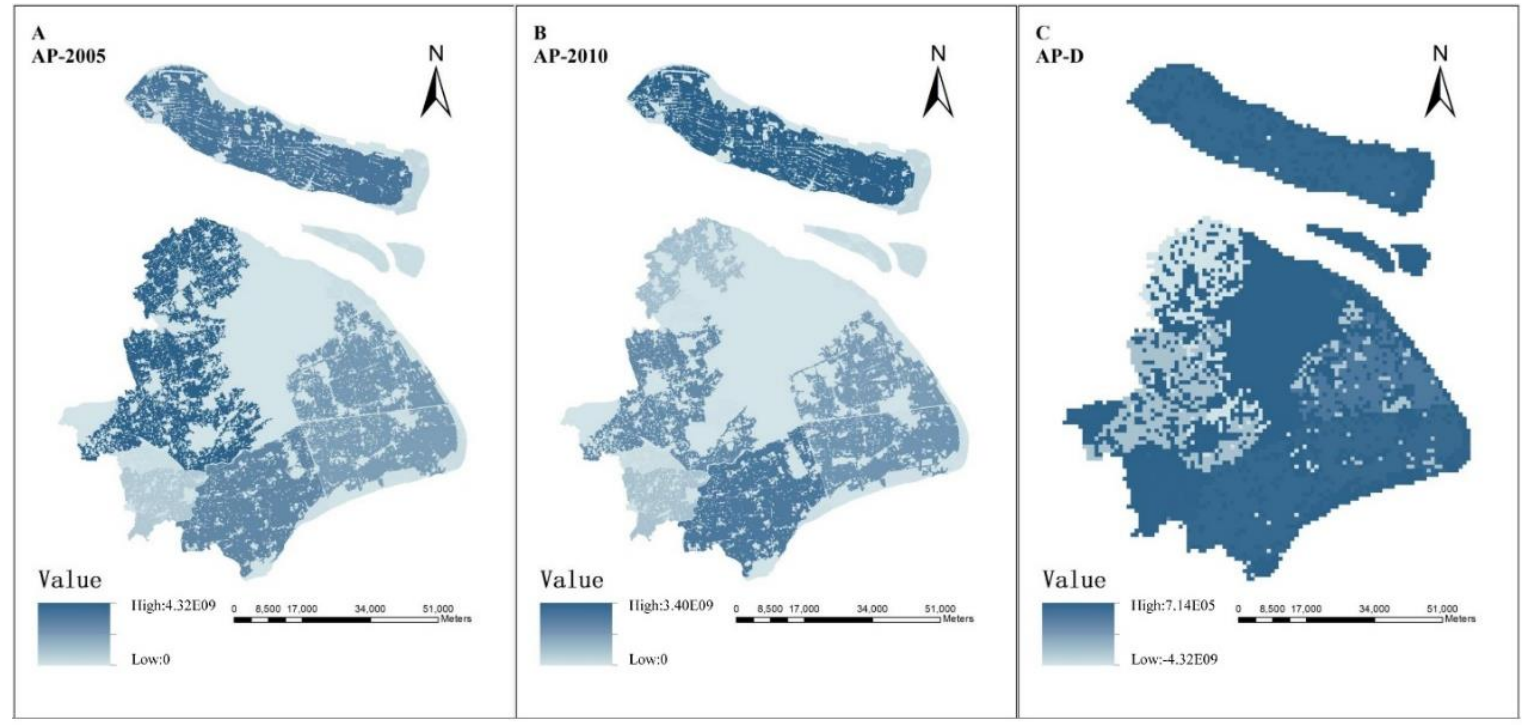

Figure 6. Spatial and temporal change of air purification service in Shanghai (sej/yr). (A) spatial distribution of AP in 2005; (B) spatial distribution of AP in 2010; (C) spatial change of AP.

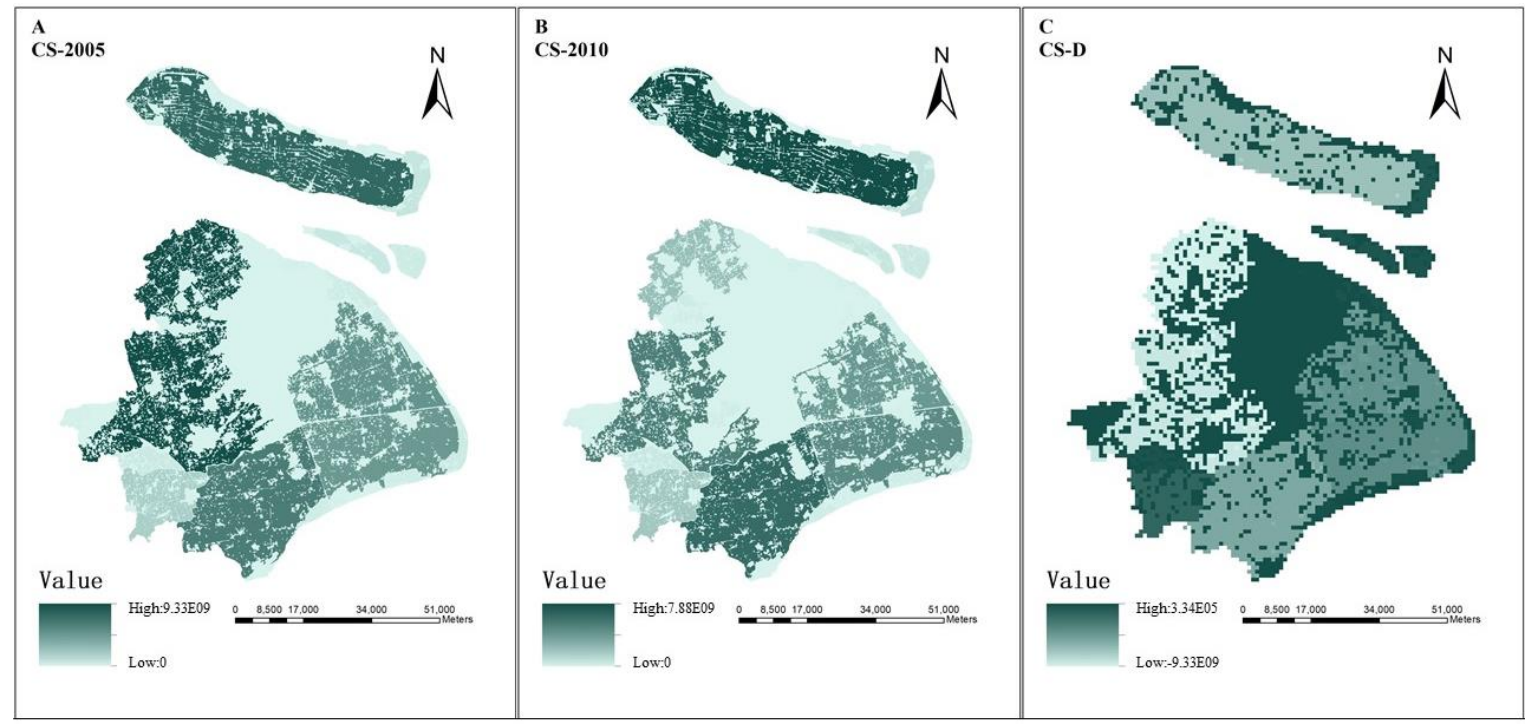

Figure 7. Spatial and temporal change of carbon sequestration service in Shanghai (sej/yr). (A) spatial distribution of CS in 2005; (B) spatial distribution of CS in 2010; (C) spatial change of CS. 


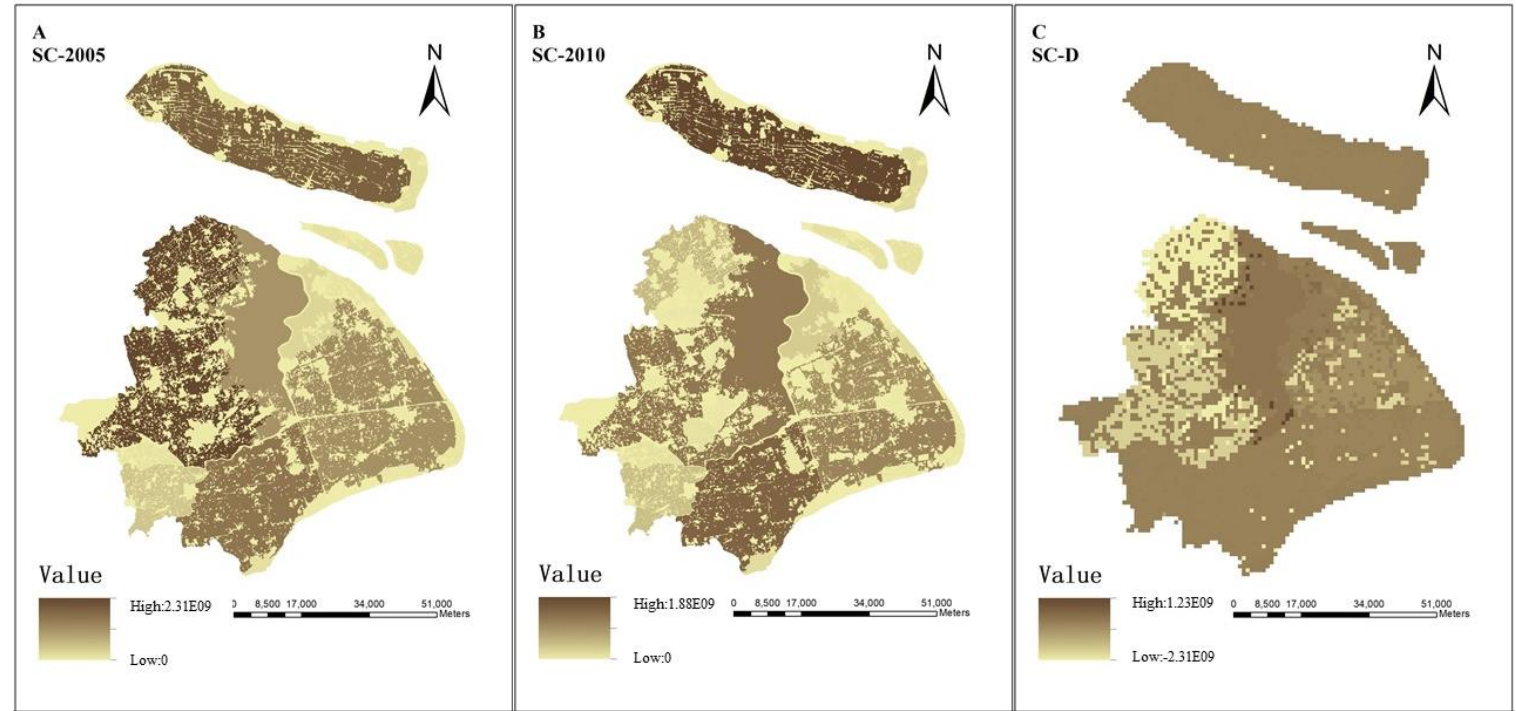

Figure 8. Spatial and temporal change of soil conservation service in Shanghai (sej/yr). (A) spatial distribution of SC in 2005; (B) spatial distribution of SC in 2010; (C) spatial change of SC.

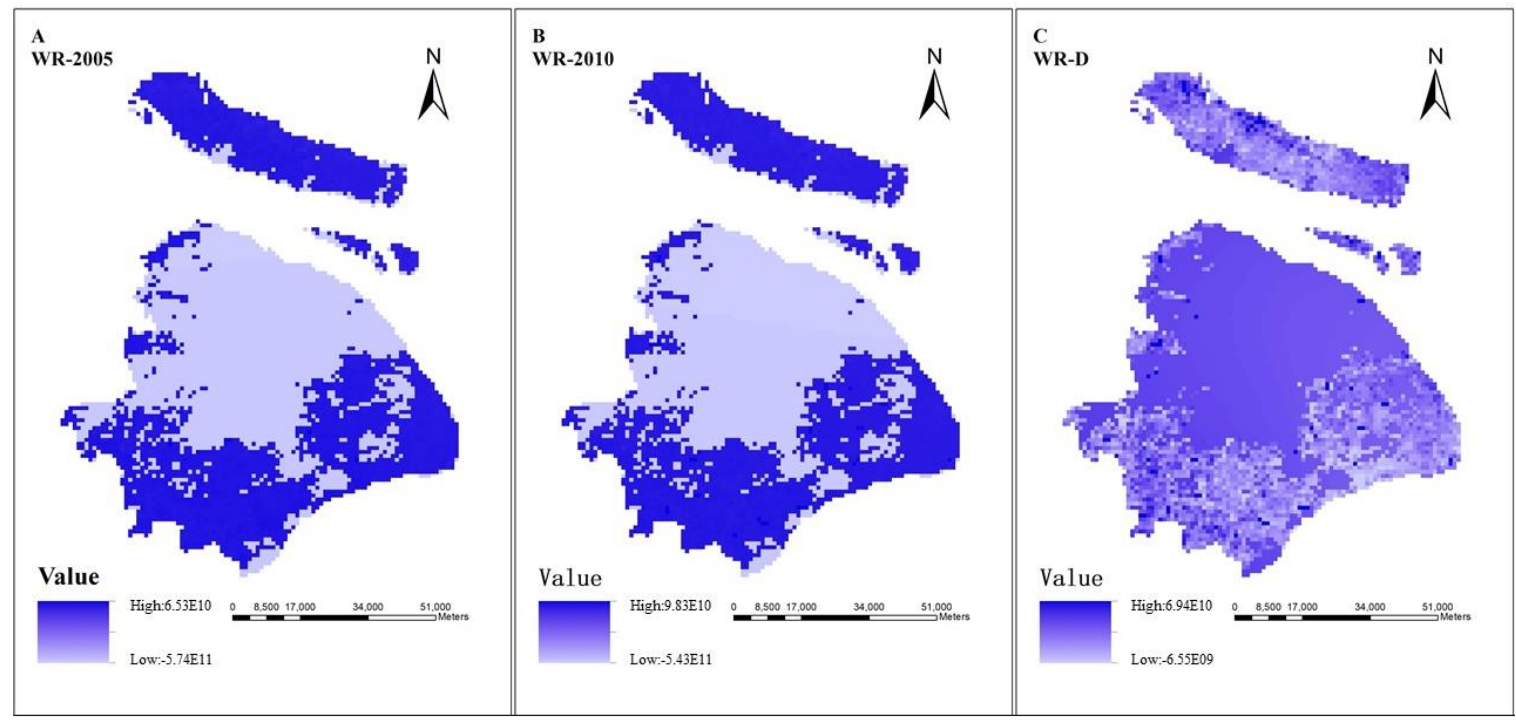

Figure 9. Spatial and temporal change of water retention service in Shanghai (sej/yr). (A) spatial distribution of WR in 2005; (B) spatial distribution of WR in 2010; (C) spatial change of WR. 


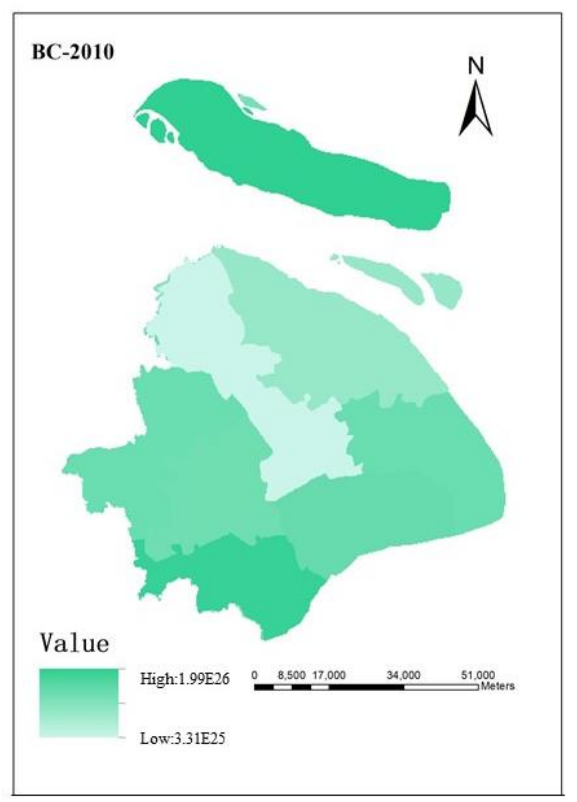

Figure 10. Spatial pattern of biodiversity conservation service of Shanghai in 2010 (sej/yr).
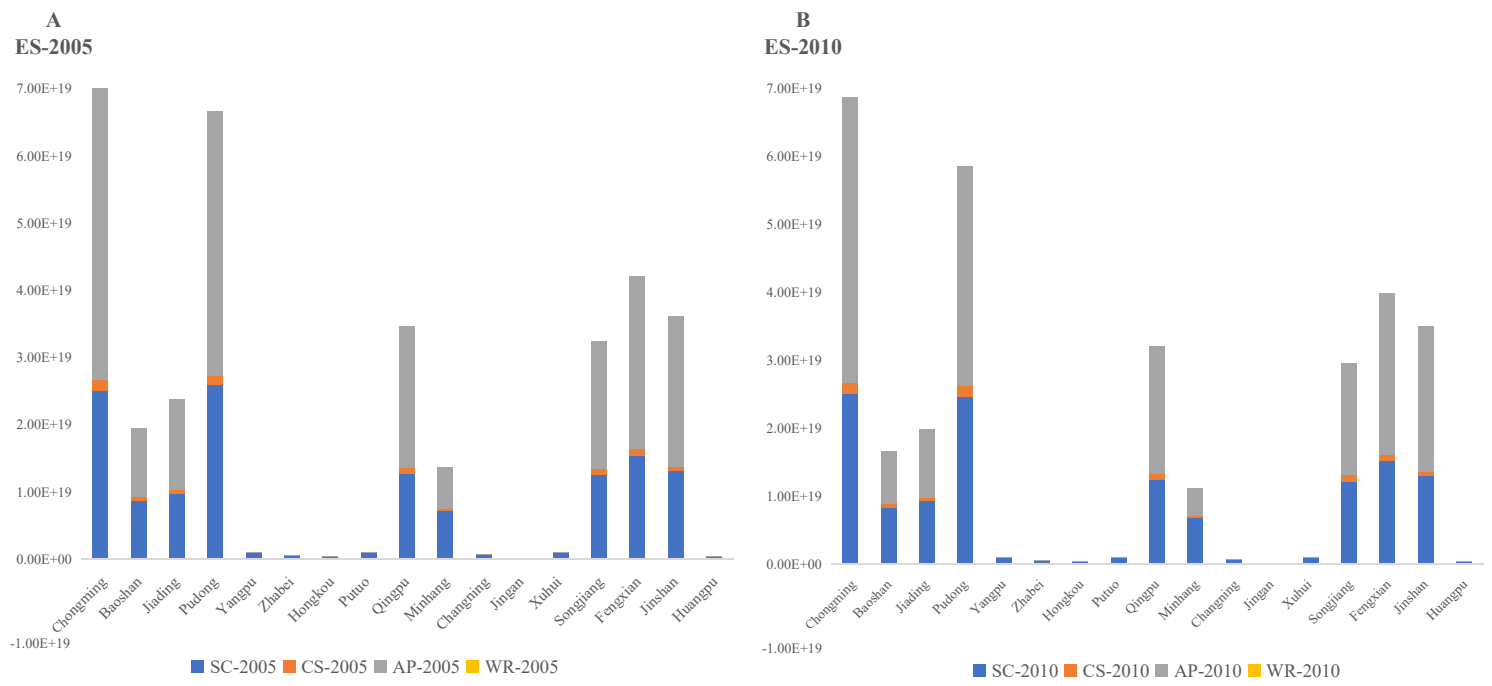

Figure 11. ESs values at the district level in Shanghai (sej/yr). (A): ESs value in 2005 at the district level;

(B): ESs value in 2010 at the district level.

Figure 12 shows the changing trend of different compositions of the total ES, while Figure 13 shows the contributions from different land types. In 2005, SC, CS, AP, and WR contributed $39.34 \%$, $2.33 \%, 58.36 \%$, and $0.00 \%$ to the total ES, respectively. In 2010, SC, CS, AP, and WR contributed $41.71 \%$, $2.56 \%, 55.76 \%, 0.00 \%$ to the total ES, respectively. AP contributed the most to the total ES, followed by SC and CS, both in 2005 and 2010. The value of the total ES decreased by $8.24 \%$ from $3.45 \times 10^{20}$ sej in 2005 to $3.16 \times 10^{20}$ sej in 2010 . AP decreased by $12.34 \%$ from $2.01 \times 10^{20}$ sej in 2005 to $1.76 \times 10^{20}$ sej in 2010. SC decreased by $2.74 \%$ from $1.36 \times 10^{20}$ sej in 2005 to $1.32 \times 10^{20}$ sej in 2010 . CS increased by $0.63 \%$ from $8.04 \times 10^{18}$ sej in 2005 to $8.09 \times 10^{18}$ sej in 2010 . Finally, WR increased by $10.07 \%$ from $-1.59 \times 10^{15}$ sej in 2005 to $-1.43 \times 10^{15}$ sej in 2010 . Obviously, AP had the largest decrease during the study period. From a land-use point of view, ES from the crop land system contributed the most to the total ES (85.91\% in 2005 and $82.24 \%$ in 2010), followed by the built-up land (8.68\% in 2005 and $11.51 \%$ in 2010), and the forest land (4.09\% in 2005 and $4.74 \%$ in 2010). AP is mainly contributed by the crop land (94.49\% in 2005 and $93.60 \%$ in 2010), followed by forest land (3.85\% in 2005 and $4.61 \%$ in 2010). 
SC is mainly contributed by crop land (75.24\% in 2005 and 69.24\% in 2010), followed by the builtup land (22.06\% in 2005 and $27.61 \%$ in 2010). CS is mainly contributed by forest land (48.65\% in 2005 and $52.43 \%$ in 2010) and crop land (51.14\% in 2005 and $47.36 \%$ in 2010). Finally, WR is mainly contributed by the water area (46.94\% in 2005 and $58.65 \%$ in 2010) and the crop land (43.09\% in 2005 and $30.31 \%$ in 2010). However, the area of crop land had the largest decrease during the study period and there will be a 36.84\% decrease in crop land from 2015 to 2035 according to Shanghai Master Plan 2017-2035. Therefore, to compensate for the loss of ESs caused by the decrease of crop land is of great importance.

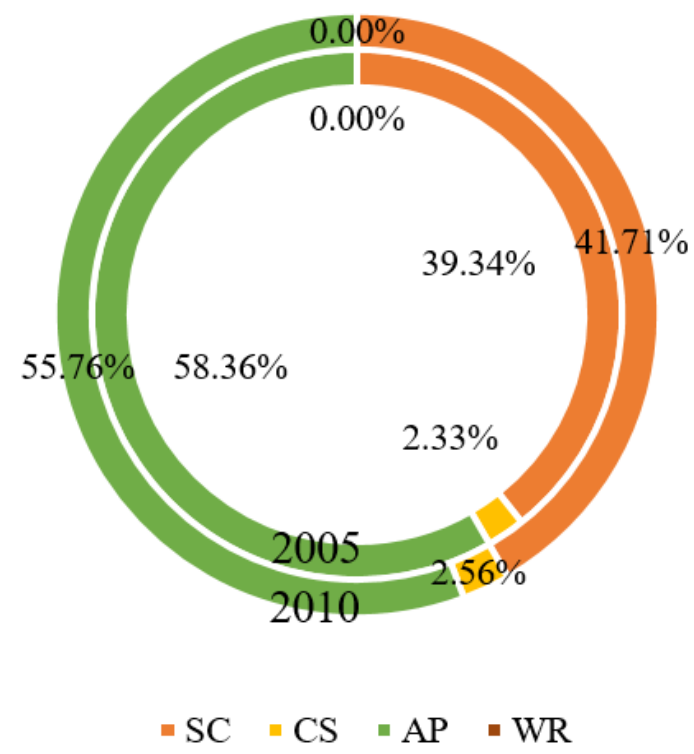

Figure 12. Changing trend of total ESs composition in Shanghai.

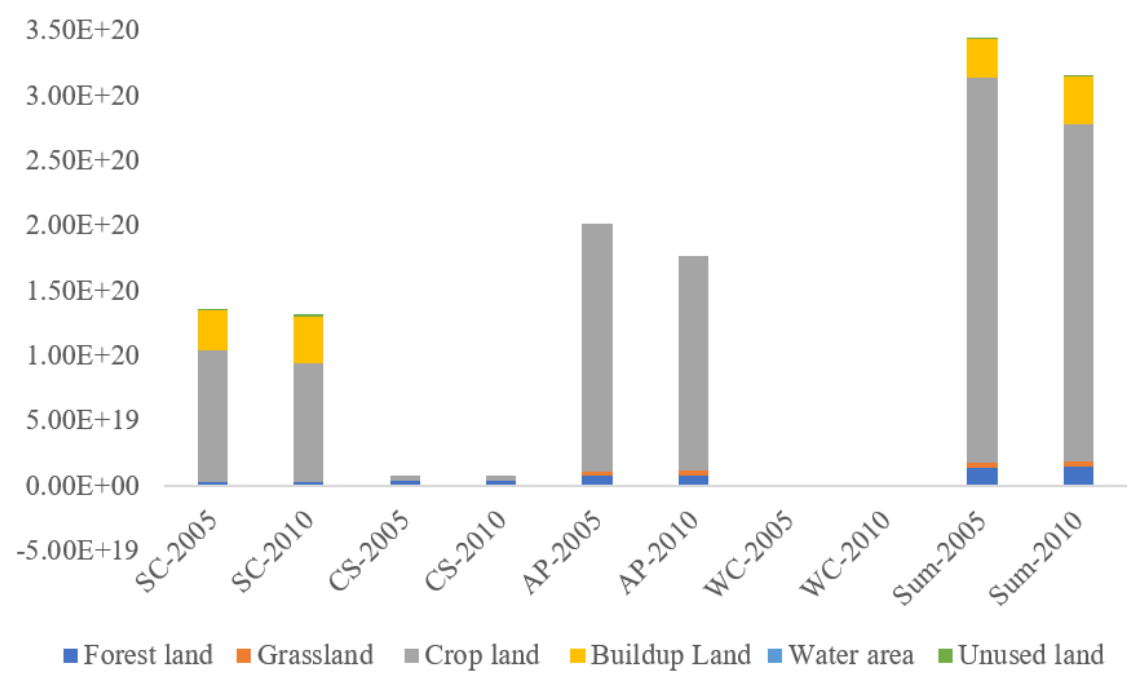

Figure 13. Changing trend of ecosystem services in Shanghai (sej/yr).

\subsection{ESs Trade-Offs and Synergy}

Figure 14 shows the relationships between various ESs. The most points in Figure $14 \mathrm{~A}-\mathrm{C}$ appear in the down-left quadrant, indicating the synergy between these ESs. Figure 14D-F demonstrated the trade-off relationships between WR and other ESs. Correlations among different ESs at the grid level are listed in Table 4. The results show that SC and AP had the most correlated relationship, followed by SC and CS. The correlation relationships between WR and others were weak, while negative correlation relationships between WR and AP, WR and SC were observed. Besides, the biodiversity conservation 
and the total ES were largely correlated in 2010 (Pearson correlation coefficient $=0.979$ ). This result is not surprising since biodiversity plays a core role in producing ESs [32].
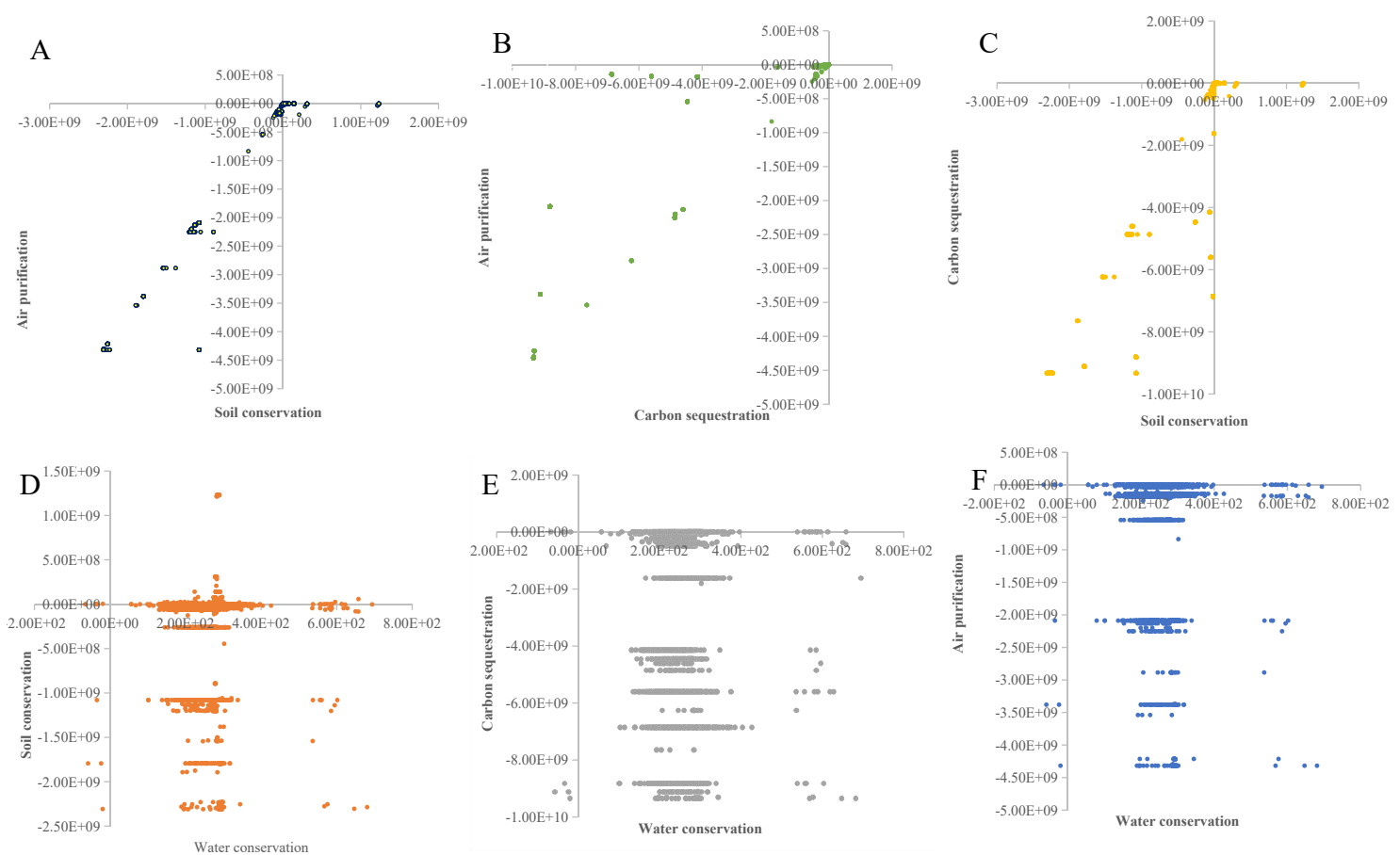

Figure 14. Trade-offs and synergies among the considered ESs at grid scaled level: (A) air purification vs. soil conservation, (B) air purification vs. carbon sequestration, (C) carbon sequestration vs. soil conservation, (D) water retention vs. soil conservation, (E) water retention vs. carbon sequestration, (F) water retention vs. air purification.

Table 4. Pearson correlation coefficient of the regulation of ecosystem services.

\begin{tabular}{ccccc}
\hline & WR & SC & CS & AP \\
\hline WR & 1 & & & \\
SC & -0.105 & 1 & & \\
CS & 0.065 & 0.688 & 1 & \\
AP & -0.123 & 0.975 & 0.696 & 1 \\
\hline
\end{tabular}

\subsection{The Impacts of Urbanization on ESS}

The spatial changes in grid-scaled GDP and population from 2005 to 2010 are shown in Figure 15. Table 5 lists the values of urbanization indicators in 2005 and 2010 at the district level. Relationships between the total ES and the urbanization indicators at the district level were explored by using the curve estimations (Figure 16). 


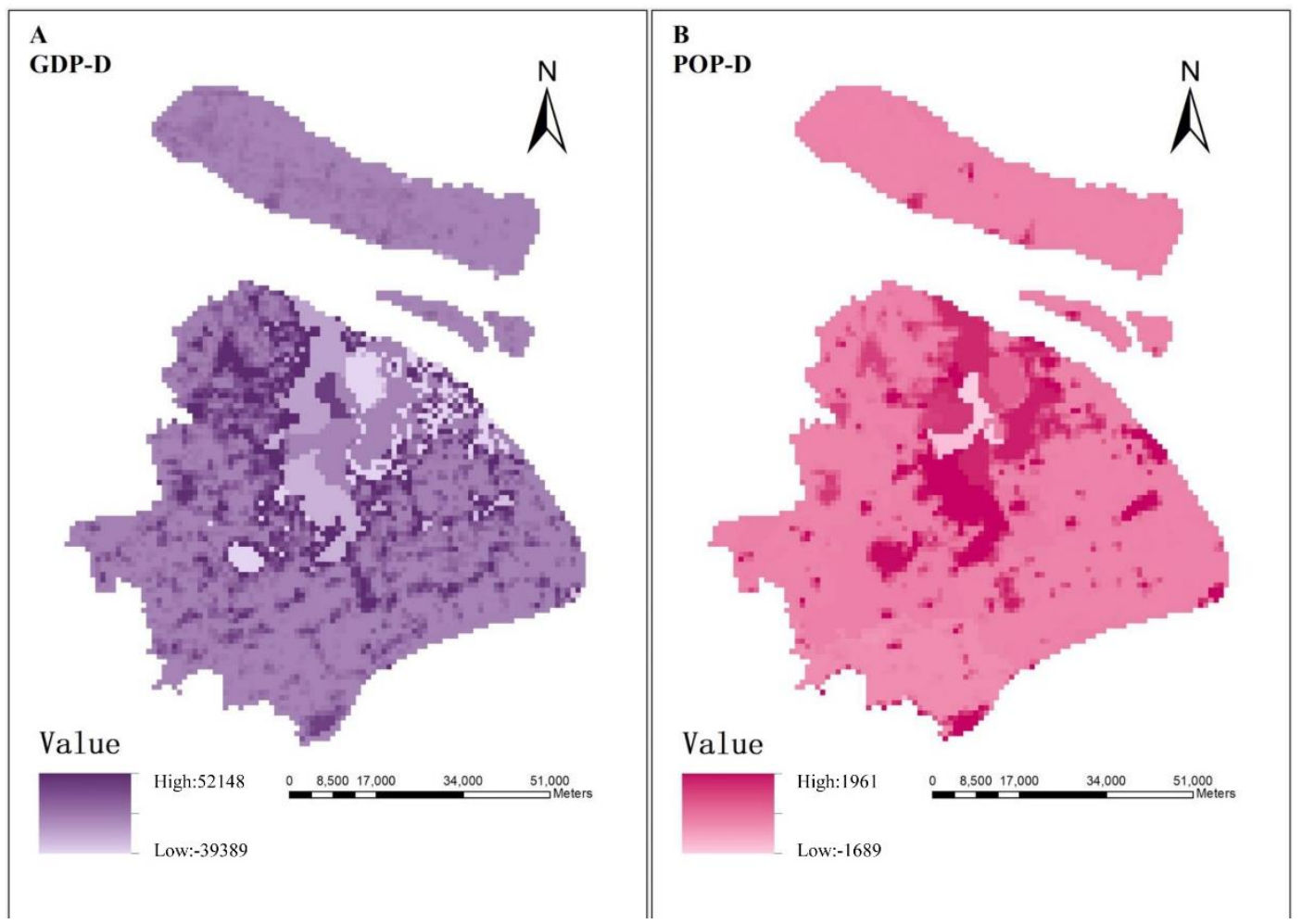

Figure 15. Spatial changes in GDP and population from 2010 to 2005 in Shanghai. (A): change of GDP, (B): change of population.

The results from the curve estimations show that the increase of urbanization indicators and the decrease of ESs can be characterized by a cubic polynomial, and the irregular " $U$ " shape relationship between the decrease of ESs and the increase of urbanization indicators are observed. In the beginning, with the increase of built-up land and GDP of the manufacturing industry, the decrease of ESs experienced an upward trend. The turning point is observed when the increase in built-up land and GDP of the manufacturing industry reach $2.00 \times 10^{3}$ and $1.50 \times 10^{3}$, respectively. The decrease of ESs remains steady before the increase in the built-up land and GDP of the manufacturing industry reach $5.00 \times 10^{3}$ and $3.00 \times 10^{3}$. After these points, the decrease of ESs experienced a rapid upward trend. Finally, an overt linear relationship between the decrease of ESs and the increase of population appears.

Figure 17 shows the values of urbanization elasticity of ESs from decoupling analysis at the district level. All elasticity values except the population elasticity in Changning range from 0 to 0.8 , indicating the weak decoupling of ESs decrease from urbanization. The value of population elasticity in Changning equals 1.1201, which reflects the expansive coupling of ESs decrease from population growth. Jingan district shows a strong negative decoupling of ESs decrease from population growth, mainly because the population in Jingan declined. According to the decoupling theory, when the two parameters are larger than 0, a larger value of elasticity indicates decreased ESs, reflecting the higher pressure of urbanization on the ecosystem. Besides, when the elasticity value is close to 0.8 , it indicates the potential trend toward expansive coupling. Putuo had the largest value of the buildup land elasticity of ESs, with a figure of 0.4454. Banshan had the largest value of GDP elasticity of ESs, with a figure of 0.6052 . Changning had the largest value of population elasticity of ESs, indicating the potential expansive coupling trends of ESs decreasing from these urbanization indicators. Finally, the values of urbanization elasticity of ESs in Yangpu, Zhabei, Hongkou, Jingan, Xuhui, and Huangpu are equal to 0 , which is mainly because the values of ESs in these districts remain unchanged during the study period. 
Table 5. District-level urbanization indicators in Shanghai.

\begin{tabular}{|c|c|c|c|c|c|c|}
\hline Districts & $\begin{array}{c}\text { GDP of } \\
\text { Secondary } \\
\text { Industry in } 2005 \\
\left(1 \times 10^{8} \text { Yuan }\right)\end{array}$ & $\begin{array}{c}\text { GDP of } \\
\text { Secondary } \\
\text { Industry in } 2010 \\
\left(1 \times 10^{8} \text { Yuan }\right)\end{array}$ & $\begin{array}{l}\text { Population in } \\
2005\left(1 \times 10^{4}\right)\end{array}$ & $\begin{array}{l}\text { Population in } \\
2010\left(1 \times 10^{4}\right)\end{array}$ & $\begin{array}{c}\text { Built-up } \\
\text { Land in } 2005 \\
\left(1 \times 10^{4} \mathrm{~m}^{2}\right)\end{array}$ & $\begin{array}{c}\text { Built-up } \\
\text { Land in } 2010 \\
\left(1 \times 10^{4} \mathrm{~m}^{2}\right)\end{array}$ \\
\hline Chongming & 132.66 & 422.31 & 65.68 & 70.34 & 646 & 1628 \\
\hline Baoshan & 2406.44 & 2992.43 & 130.54 & 190.56 & 4793 & 7248 \\
\hline Jiading & 1341.72 & 3465.94 & 94.28 & 147.2 & 3980 & 7073 \\
\hline Pudong & 4673.14 & 9422.72 & 367.76 & 504.73 & 10,430 & 18,270 \\
\hline Yangpu & 549.76 & 1046.49 & 120.32 & 131.3 & 4155 & 4730 \\
\hline Zhabei & 223.74 & 506.76 & 75.81 & 83.04 & 2570 & 2797 \\
\hline Hongkou & 204.31 & 408.52 & 78.26 & 85.23 & 2874 & 3192 \\
\hline Putuo & 308.08 & 542.48 & 110.6 & 128.88 & 4262 & 5146 \\
\hline Qingpu & 742.84 & 1387.87 & 73.75 & 108.19 & 1411 & 4169 \\
\hline Minhang & 1682.98 & 3779.57 & 170.76 & 243.12 & 6390 & 12,221 \\
\hline Changning & 164.73 & 286.44 & 67.18 & 69.06 & 2900 & 3419 \\
\hline Jingan & 72.56 & 84.21 & 25.65 & 24.67 & 1491 & 1593 \\
\hline Xuhui & 787.96 & 1062.73 & 98.59 & 108.52 & 4187 & 6332 \\
\hline Songjiang & 2060.16 & 4380.91 & 88.58 & 158.34 & 6318 & 8109 \\
\hline Fengxian & 549.16 & 1409.92 & 73.44 & 108.41 & 1359 & 1866 \\
\hline Jinshan & 839.07 & 1542.38 & 59.21 & 73.25 & 1438 & 2526 \\
\hline Huangpu & 336.68 & 414.2 & 78.01 & 67.84 & 3111 & 3270 \\
\hline
\end{tabular}
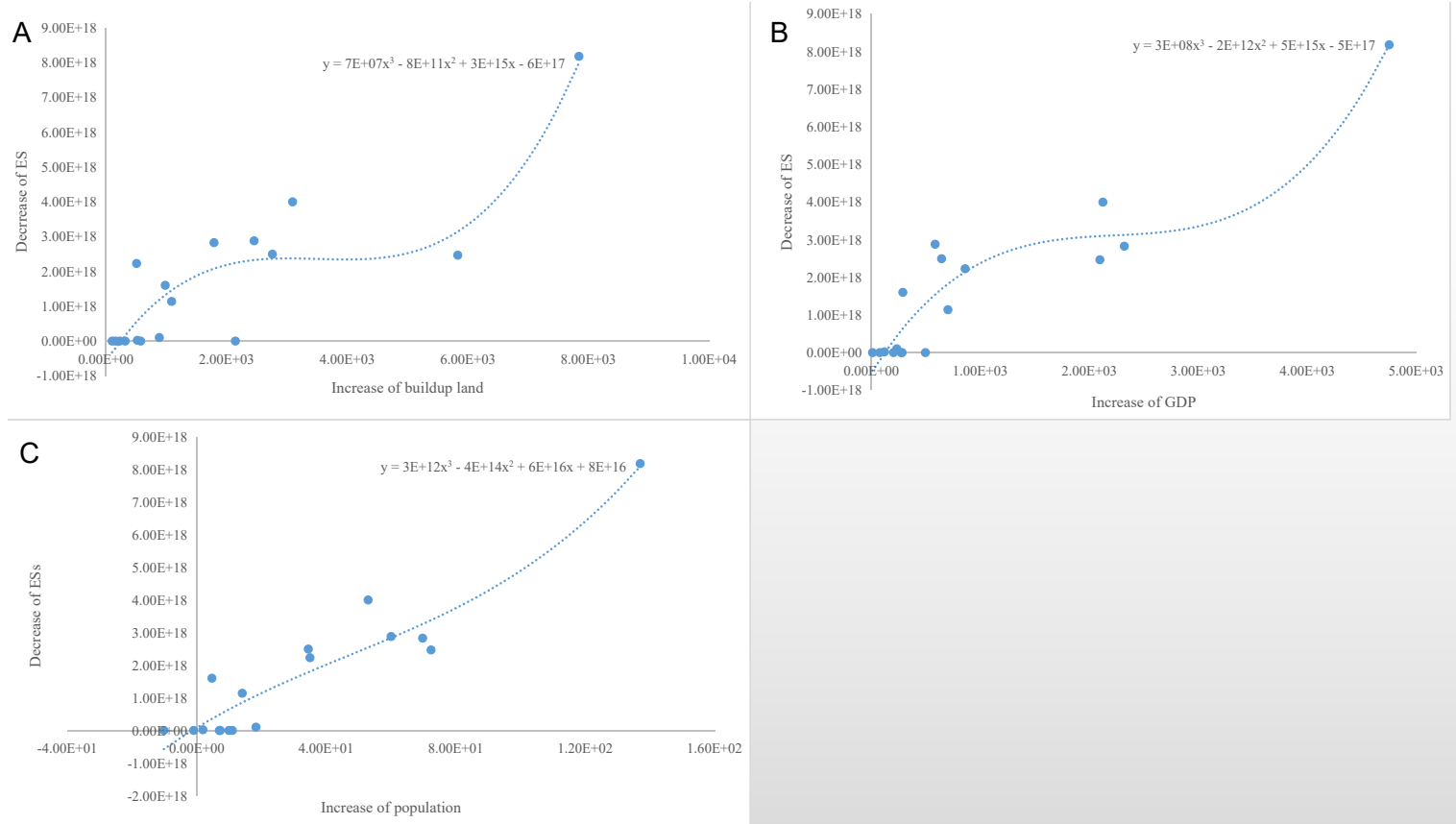

$-1.00 \mathrm{E}+18$ Increase of GDP

Figure 16. Relationships between the decrease of total ESs and urbanization indicators. (A): built-up land vs. ESs, (B): GDP vs. ESs, (C): population vs. ESs.

\subsection{Research Limitations and Future Prospective}

Due to a lack of sufficient data, this study did not quantify all the ESs, but only those core ESs identified by previous studies. Beyond the considered ESs, the worldwide significant overuses of ESs, such as phosphorus and nutrient cycles, should be also considered in future studies. In addition, this study only quantified the biodiversity conservation for the year 2010, leading to a lack of a dynamic picture of biodiversity conservation. The year 2010 was chosen as the last year of this study because social and economic data (including spatial distributions of GDP and population) are not available for more recent years. Finally, although we proposed this framework to evaluate water pollutant purification services, such a value was not quantified due to the lack of basic data. Further studies can complement these issues when the relevant data are available. 


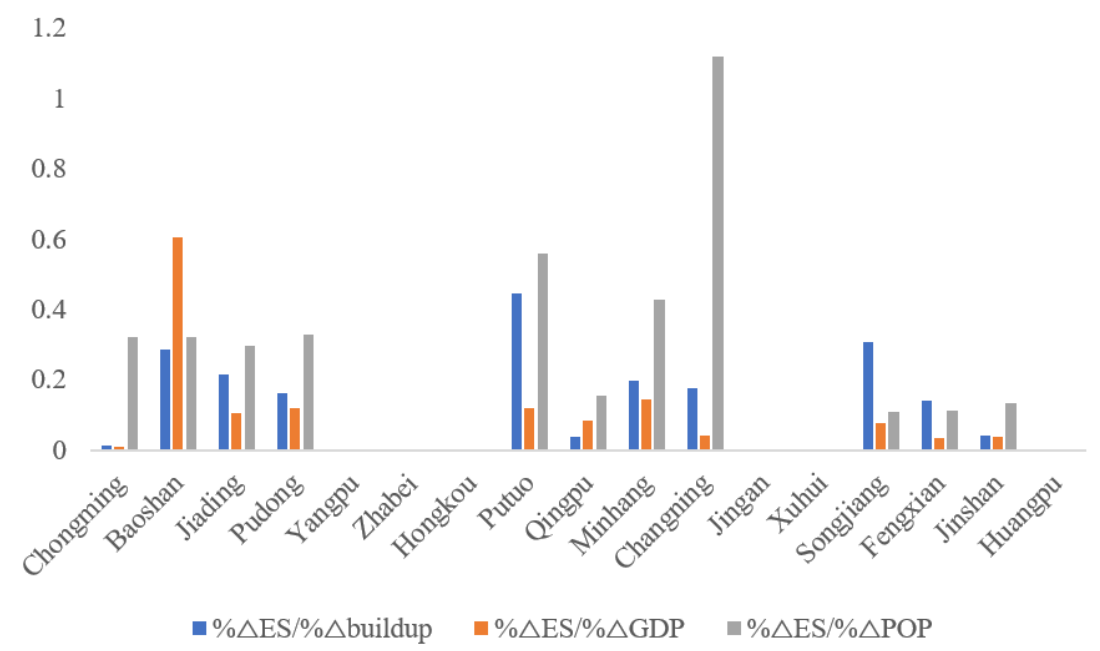

Figure 17. Values of urbanization elasticity of ESs at the district-level.

There are several research directions for future studies. Firstly, the impacts of urbanization on ESs demanded by the socioeconomic system and the driving factors can be further studied so that more appropriate recommendations can be raised. Additionally, Shanghai is the most advanced city in China and may have pressure on the broader ecosystem beyond its administrative boundaries, indicating that the teleconnection effect should be taken into consideration in a future study. Finally, it is crucial to further investigate the relationships among fundamental supporting ESs, intermediate ESs, final ESs, and ecosystem structure and functions so that a more complete picture of the ESs process can be uncovered.

\section{Conclusions}

China's rapid urbanization and economic growth have led to the great change of ecosystem functions. Understanding the relationship between urbanization and ecosystem services is of critical importance to achieving China's ecological civilization targets and the UN's SDGs. Under such a circumstance, this study proposes an emergy-GIS-based framework to evaluate the ESs with consideration of the contribution of Shanghai, one of the most economically advanced and populous cities in China and the world. Then, the tradeoffs among different kinds of ESs and the relationships between urbanization indicators and ESs were explored. Finally, a decoupling analysis was conducted to identify the decoupling state of ESs from urbanization.

The results reflect that the area of crop land decreased by $10.26 \%$ during the study period, while the area of forest land, unused land, and built-up land increased by $4.31 \%, 36.88 \%$, and $21.72 \%$, respectively. Shanghai's total ecosystem service value declined by $8.24 \%$ from $3.45 \times 10^{20}$ sej in 2005 to $3.16 \times 10^{20}$ sej in 2010, mainly contributed by the AP decrease from $2.01 \times 10^{20}$ sej in 2005 to $1.76 \times 10^{20}$ sej in 2010 . ES of the crop land system contributed the most to the total ES. At the district level, Chongming had the highest value of ES, followed by Pudong and Fengxian. The irregular " $U$ " shape relationships between the decreases of ESs and the increases of urbanization indicators in Shanghai were observed. Synergy relationships among AP, CS, and SC exist, while tradeoff between WR and others can be observed. Finally, most districts experienced the weak decoupling of ESs decrease from urbanization. Results from such a systematic framework can help provide insightful policy implications to move toward sustainable urbanization. To improve the relationships between various ESs and urbanization, we propose the following policy recommendations to the city of Shanghai and other cities facing similar challenges.

Firstly, urban planners should fully consider all the relevant ES information into their urban plans so that sustainable urban policies can be made. Detailed data should include natural hydrologic and ecological processes, spatial patterns, and dynamic changes of ESs and the synergies and tradeoff 
relationships among various ESs. For example, our results reflect that the top priority should be given to Chongming and Pudong due to their dominating roles in producing ESs, while Minhang, Jiading, Baoshan, and Pudong also deserve considerable attention due to their decreased ESs during the study period. Spatial heterogeneity in different districts requires more region-specific mitigation policies.

Secondly, a nature-based solution [82] should be carefully employed. Detailed actions include planned ecological redline areas [32], tree-planting campaigns, expanding urban forest and urban parks [83], and the establishment of ecological corridors. Besides, compact use of the built-up land and optimized land planning is effective to overcome the sprawling expansion of the built-up land. Moreover, actions should be taken to compensate for the loss of ESs caused by the crop land decrease.

Finally, it is necessary to adopt this framework to build up an ESs evaluation database covering different regions and cities so that different stakeholders can share related knowledge and information. Such a database can also help decision-makers to dynamically monitor local ecosystems and prepare more appropriate urban policies so that cities can move toward sustainable urban development.

Author Contributions: Conceptualization, H.P. and W.H.; Funding acquisition, Y.G.; Investigation, J.H. and W.H.; Methodology, H.P., Y.G., C.H. and Z.M.; Project administration, Y.G.; Visualization, J.H.; Writing-original draft, H.P. and Y.G. All authors have read and agreed to the published version of the manuscript.

Funding: This study research was funded by the National Key Research and Development Project (2019YFC1908501), the Natural Science Foundation of China (72088101, 7169024, 71810107001, 71704104, 71774100, 71804071).

Conflicts of Interest: The authors declare no conflict of interest.

\section{Appendix A}

Table A1. The capacities of ecosystems to purify pollutants.

\begin{tabular}{|c|c|c|c|c|c|c|c|c|c|}
\hline $\begin{array}{l}\text { Land } \\
\text { Types }\end{array}$ & $\begin{array}{c}\mathrm{SO}_{2} \\
\left(\mathrm{~kg} / \mathrm{hm}^{2}\right)\end{array}$ & $\begin{array}{c}\mathrm{PM}_{10} \\
\left(\mathrm{~kg} / \mathrm{hm}^{2}\right)\end{array}$ & $\mathrm{PM}_{2.5}\left(\mathrm{~kg} / \mathrm{hm}^{2}\right)$ & $\mathrm{NO}_{\mathbf{x}}$ & Fluoride & $\mathbf{M}_{\mathrm{cu}}$ & $\mathbf{M}_{\mathrm{mn}}$ & $\mathbf{M}_{\mathbf{z n}}$ & $\mathbf{M}_{\mathrm{pb}}$ \\
\hline Forest land & 97.73 & 10.67 & 2.65 & 6.80 & 8.99 & - & - & - & - \\
\hline Grassland & 79.7097 & 1.7994 & - & - & - & 27.7 & 1823.1 & 94.4 & 46.6 \\
\hline Crop land & 45.00 & 1.0999 & - & 33.25 & 0.48 & - & - & - & - \\
\hline
\end{tabular}

Table A2. Pollutants considered and the related impacts.

\begin{tabular}{|c|c|c|c|c|}
\hline Items & $\begin{array}{l}\text { Damage Category } \\
\text { to Human Health }\end{array}$ & $\begin{array}{c}\text { DALYs/kg of } \\
\text { Emission }\end{array}$ & $\begin{array}{l}\text { Damage to } \\
\text { Ecosystem }\end{array}$ & PDF $\mathrm{m}^{2} \mathrm{yr}$ \\
\hline $\mathrm{SO}_{2}$ & Respiratory effects & $5.46 \times 10^{-5}$ & $\begin{array}{l}\text { Acidification and } \\
\text { eutrophication }\end{array}$ & 1.04 \\
\hline $\mathrm{PM}_{2.5}$ & Respiratory effects & $7.00 \times 10^{-4}$ & $1-$ & - \\
\hline $\mathrm{PM}_{10}$ & Respiratory effects & $3.75 \times 10^{-4}$ & - & - \\
\hline $\mathrm{NOx}$ & Respiratory effects & $8.87 \times 10^{-5}$ & $\begin{array}{l}\text { Acidification and } \\
\text { eutrophication }\end{array}$ & 5.71 \\
\hline Fluoride & Climate change & $7.48 \times 10^{-4}$ & - & - \\
\hline $\mathrm{Cu}$ & - & - & Ecotoxic substances & 10.81 \\
\hline Mn & - & - & - & - \\
\hline $\mathrm{Zn}$ & - & - & Ecotoxic substances & 22.66 \\
\hline $\mathrm{Pb}$ & - & - & Ecotoxic substances & 0.09 \\
\hline
\end{tabular}


Table A3. Biomass in Shanghai estimated from [32] (tonnes/ha).

\begin{tabular}{cccccc}
\hline Land Types & $\begin{array}{c}\text { Aboveground } \\
\text { Biomass }\end{array}$ & $\begin{array}{c}\text { Belowground } \\
\text { Biomass }\end{array}$ & Soil & $\begin{array}{c}\text { Dead Organic } \\
\text { Matter }\end{array}$ & Total Amounts \\
\hline Forest land & 350 & 240 & 260 & 110 & 960 \\
Grassland & 8 & 8 & 30 & 2 & 48 \\
Crop land & 5 & 3 & 18 & 1 & 27 \\
Water area & 0 & 0 & 0 & 0 & 0 \\
Buildup Land & 0 & 0 & 0 & 0 & 0 \\
Unused Land & 0 & 0 & 0 & 0 & 0 \\
\hline
\end{tabular}

Table A4. The parameters related to soil conservation in Shanghai.

\begin{tabular}{ccccccc}
\hline & Forest Land & Grassland & Crop Land & $\begin{array}{c}\text { Buildup } \\
\text { Land }\end{array}$ & Water Area & $\begin{array}{c}\text { Unused } \\
\text { Land }\end{array}$ \\
\hline $\mathrm{C}$ & 0.11 & 0.5 & 0.21 & 0.27 & - & 0.77 \\
$\mathrm{LS}$ & 0.1 & 0.1 & 0.1 & 0.1 & - & 0.1 \\
$\mathrm{P}$ & 1 & 1 & 0.01 & 1 & - & 1 \\
$\mathrm{R}\left(\mathrm{MJ} \mathrm{mm} \mathrm{ha} \mathrm{h}^{-1} \mathrm{yr}^{-1}\right.$ & 4594.66 & 4594.66 & 4594.66 & 4594.66 & - & 4594.66 \\
$\mathrm{~K}\left(\mathrm{tha} \mathrm{h} \mathrm{ha} \mathrm{MJ}^{-1} \mathrm{~mm}^{-1}\right)$ & 0.038 & 0.038 & 0.038 & 0.038 & - & 0.038 \\
\hline
\end{tabular}

Table A5. UEVs used in this study based on $12.0 \times 10^{24} \mathrm{sej} / \mathrm{yr}$ emergy baseline.

\begin{tabular}{llcc}
\hline \multicolumn{2}{l}{ Items } & UEVs & Reference \\
\hline 1. & Solar radiation & $1 \mathrm{sej} / \mathrm{J}$ & By definition \\
2. $\quad$ Geothermal heat & $4.90 \times 10^{3} \mathrm{sej} / \mathrm{J}$ & {$[66]$} \\
3. Tidal energy & $3.09 \times 10^{4} \mathrm{sej} / \mathrm{J}$ & {$[66]$} \\
4. Wind, kinetic energy & $7.90 \times 10^{2} \mathrm{sej} / \mathrm{J}$ & {$[66]$} \\
5. Rain, chemical potential & $7.01 \times 10^{3} \mathrm{sej} / \mathrm{J}$ & {$[66]$} \\
6. Runoff, geopotential energy & $1.28 \times 10^{4} \mathrm{sej} / \mathrm{J}$ & {$[66]$} \\
7. Runoff, chemical potential & $2.13 \times 10^{4} \mathrm{sej} / \mathrm{J}$ & {$[66]$} \\
8. Wave energy & $4.20 \times 10^{3} \mathrm{sej} / \mathrm{J}$ & {$[66]$} \\
9. Soil & $1.42 \times 10^{10} \mathrm{sej} / \mathrm{kg}$ & {$[31]$} \\
10. $\quad$ Fresh water & $1.00 \times 10^{8} \mathrm{sej} / \mathrm{kg}$ & {$[31]$} \\
11. $\quad$ Biomass $(2005)$ & $7.27 \times 10^{8} \mathrm{sej} / \mathrm{kg}$ & This study \\
12. $\quad$ Biomass $(2010)$ & $7.57 \times 10^{8} \mathrm{sej} / \mathrm{kg}$ & This study \\
\hline
\end{tabular}

Note:

1. Earth's climate system is driven by solar radiation. Satellite-derived daily solar radiation $\left(R_{S}\right)$ is of low accuracy in its depiction [84]. In this study, Sunshine Duration (SunDu) was employed as proxy record of $R_{S}$. The average daily solar radiation equals to $145.7 \mathrm{Wm}^{-2}$ in Shanghai [84]. Solar energy $(\mathrm{J})=($ area $) \times($ avg insolation $) \times(1$-albedo $) \times($ Carnot efficiency $)$ avg insolation $=$ SunDu $\times$ averaged $\mathrm{R}_{\mathrm{S}}$ Albedo $=30.00 \%$ of insolation Carnot efficiency $=93.00 \%$ [66] .

2. Tidal energy $(\mathrm{J})=($ area $)(0.5)($ tides $/ \mathrm{y})(\text { mean tidal range })^{2}$ (density of seawater)(gravity) Area $=6.34 \times 10^{9} \mathrm{~m}^{2}$; Tides/year $=7.30 \times 10^{2}[66] ;$ Avg tide range $=3.30$ and $3.40 \mathrm{~m}$ in 2005 and 2010, respectively (Water Resources Bulletin of Shanghai (2010, 2005); Percent absorbed $=50 \%$; Density of seawater $=1.03 \times 10^{3} \mathrm{~kg} \mathrm{~m}^{-3}$; Gravity $=9.8 \mathrm{~m} \mathrm{~s}^{-2}$.

3. Earth cycle heat flow energy $(\mathrm{J})=($ area $)$ (heat flow $)\left(\right.$ carnot efficiency) Area $=6.34 \times 10^{9} \mathrm{~m}^{2}$; Heat flow $=2.00 \times 10^{6} \mathrm{~J} \mathrm{~m}^{-2} \mathrm{y}^{-1}[66]$; Carnot efficiency $=9.50 \%$; Total energy $=1.20 \times 10^{15} \mathrm{~J}$.

4. Wind energy $(\mathrm{J})=($ land area $)($ air density $)($ drag coefficient $)(\text { land wind absorbed })^{3}$; Density of air $=1.23 \mathrm{~kg} \mathrm{~m}^{-3}$; Drag coeff. $=1.64 \times 10^{-3}$ [66]; Geostrophic wind $=1.04 \times 10 \mathrm{~m} \mathrm{~s}^{-1}$ [66]; Land wind absorbed $=$ Geostrophic wind-Land wind velocity.

5. Rain, chemical potential energy $(\mathrm{J})=$ (land area)(rainfall) $(\%$ transpired $)$ (Gibbs energy of rain) Transpiration rate $=75 \%$; Gibbs energy of rain $=4.72 \times 10^{3} \mathrm{~J} \mathrm{~kg}^{-1}[66]$. 
6. Runoff, geopotential energy $(\mathrm{J})=($ land area) $(\%$ runoff $)($ rainfall $)($ avg elevation $)($ gravity $) \%$ runoff $=25 \%$; Gravity $=9.8 \mathrm{~m} \mathrm{~s}^{-2}$.

7. Runoff, chemical potential $(\mathrm{J})=$ (land area)(rainfall) $(\%$ runoff)(Gibbs energy of runoff) $\%$ runoff $=25 \%$ [66]; Gibbs energy of runoff $=4.70 \times 10^{3} \mathrm{~J} \mathrm{~kg}^{-1}$ [66]

8. Wave Energy $(\mathrm{J})=($ shore length $)(1 / 8)($ density $)($ gravity $)\left(\right.$ wave height $\left.{ }^{2}\right)($ velocity $)\left(3.14 \times 10^{7} \mathrm{~s} \mathrm{y}^{-1}\right)$ shore length of Shanghai $=213.05 \mathrm{~km}$ [85]; Wave height $=5.00 \times 10^{-1} \mathrm{~m}$; Velocity $=5.42 \mathrm{~m} \mathrm{~s}^{-1}$ [66]; gravity $=9.8 \mathrm{~m} \mathrm{~s}^{-2}$; density $=1.025 \times 10^{3} \mathrm{~kg} \mathrm{~m}^{-3}$; wave energy $=1.14 \times 10^{16} \mathrm{~J}$.

\section{References}

1. United Nations. The Sustainable Development Goals Report; United Nations Development Program (UNDP): New York, NY, USA, 2017.

2. Seto, K.C.; Guneralp, B.; Hutyra, L.R. Global forecasts of urban expansion to 2030 and direct impacts on biodiversity and carbon pools. Proc. Natl. Acad. Sci. USA 2012, 109, 16083-16088. [CrossRef] [PubMed]

3. Fang, C.; Li, G.; Wang, S. Changing and Differentiated Urban Landscape in China: Spatiotemporal Patterns and Driving Forces. Environ. Sci. Technol. 2016, 50, 2217-2227. [CrossRef] [PubMed]

4. National Bureau of Statistics of China. China Statistical Yearbook; National Bureau of Statistics of China: Beijing, China, 2018; p. 62791819. Available online: http://www.stats.gov.cn/tjsj/ndsj/2007/indexee.htm (accessed on 9 September 2019).

5. Bai, X.; Shi, P.; Liu, Y. Realizing China's urban dream. Nature 2014, 509, 158-160. [CrossRef]

6. Chen, S.; Chen, B. Changing Urban Carbon Metabolism over Time: Historical Trajectory and Future Pathway. Environ. Sci. Technol. 2017, 51, 7560-7571. [CrossRef] [PubMed]

7. Dong, N.; You, L.; Cai, W.; Li, G.; Lin, H. Land use projections in China under global socioeconomic and emission scenarios: Utilizing a scenario-based land-use change assessment framework. Glob. Environ. Chang. 2018, 50, 164-177. [CrossRef]

8. MA (Millennium Ecosystem Assessment). Millennium Ecosystem Assessment Synthesis Report; Millennium Ecosystem Assessment: Washington, DC, USA, 2005.

9. Costanza, R.; D'Arge, R.; de Groot, R.; Farber, S.; Grasso, M.; Hannon, B.; Limburg, K.; Naeem, S.; O'Neill, R.V.; Paruelo, J.; et al. The value of the world's ecosystem services and natural capital. Nature 1997, 387, 253-260. [CrossRef]

10. Daily, G.D. Nature's Services: Societal Dependence on Natural Ecosystems; Island Press: Washington, DC, USA, 1997.

11. Ouyang, Z.; Zheng, H.; Xiao, Y.; Polasky, S.; Liu, J.; Xu, W.; Wang, Q.; Zhang, L.; Xiao, Y.; Rao, E.; et al. Improvements in ecosystem services from investments in natural capital. Science 2016, 352, 1455-1459. [CrossRef]

12. Bukvareva, E.; Zamolodchikov, D.; Grunewald, K. National assessment of ecosystem services in Russia: Methodology and main problems. Sci. Total Environ. 2019, 655, 1181-1196. [CrossRef]

13. Luederitz, C.; Brink, E.; Gralla, F.; Hermelingmeier, V.; Meyer, M.; Niven, L.; Panzer, L.; Partelow, S.; Rau, A.L.; Sasaki, R.; et al. A review of urban ecosystem services: Six key challenges for future research. Ecosyst. Serv. 2015, 14, 98-112. [CrossRef]

14. Maes, M.J.A.; Jones, K.E.; Toledano, M.B.; Milligan, B. Mapping synergies and trade-offs between urban ecosystems and the sustainable development goals. Environ. Sci. Policy 2019, 93, 181-188. [CrossRef]

15. Xi, J. A Report to the 19th National Congress of the Communist Party of China; People's Publishing House: Beijing, China, 2018.

16. Wan, L.; Ye, X.; Lee, J.; Lu, X.; Zheng, L.; Wu, K. Effects of urbanization on ecosystem service values in a mineral resource-based city. Habitat Int. 2015, 46, 54-63. [CrossRef]

17. Su, S.; Li, D.; Hu, Y.; Xiao, R.; Zhang, Y. Spatially non-stationary response of ecosystem service value changes to urbanization in Shanghai, China. Ecol. Indic. 2014, 45, 332-339. [CrossRef]

18. Zhou, D.; Tian, Y.; Jiang, G. Spatio-temporal investigation of the interactive relationship between urbanization and ecosystem services: Case study of the Jingjinji urban agglomeration, China. Ecol. Indic. 2018, 95, 152-164. [CrossRef]

19. Wang, J.; Zhou, W.; Pickett, S.T.A.; Yu, W.; Li, W. A multiscale analysis of urbanization effects on ecosystem services supply in an urban megaregion. Sci. Total Environ. 2019, 662, 824-833. [CrossRef] 
20. Lyu, R.; Zhang, J.; Xu, M.; Li, J. Impacts of urbanization on ecosystem services and their temporal relations: A case study in Northern Ningxia, China. Land Use Policy 2018, 77, 163-173. [CrossRef]

21. Li, B.; Chen, D.; Wu, S.; Zhou, S.; Wang, T.; Chen, H. Spatio-temporal assessment of urbanization impacts on ecosystem services: Case study of Nanjing City, China. Ecol. Indic. 2016, 71, 416-427. [CrossRef]

22. Zhan, J.; Zhang, F.; Chu, X.; Liu, W.; Zhang, Y. Ecosystem services assessment based on emergy accounting in Chongming Island, Eastern China. Ecol. Indic. 2018. [CrossRef]

23. Tian, L.; Zhao, M.; Peng, J.; Hu, Y.; Wu, J.; Liu, Y. Ecosystem services response to urbanization in metropolitan areas: Thresholds identification. Sci. Total Environ. 2017, 607-608, 706-714. [CrossRef]

24. Radford, K.G.; James, P. Changes in the value of ecosystem services along a rural-urban gradient: A case study of Greater Manchester, UK. Landsc. Urban Plan. 2013, 109, 117-127. [CrossRef]

25. Song, W.; Deng, X. Effects of urbanization-induced cultivated land loss on ecosystem services in the north China plain. Energies 2015, 8, 5678-5693. [CrossRef]

26. Delphin, S.; Escobedo, F.J.; Abd-Elrahman, A.; Cropper, W.P. Urbanization as a land use change driver of forest ecosystem services. Land Use Policy 2016. [CrossRef]

27. Sirakaya, A.; Cliquet, A.; Harris, J. Ecosystem services in cities: Towards the international legal protection of ecosystem services in urban environments. Ecosyst. Serv. 2018, 29, 205-212. [CrossRef]

28. Ferreira, L.M.R.; Esteves, L.S.; de Souza, E.P.; dos Santos, C.A.C. Impact of the Urbanisation Process in the Availability of Ecosystem Services in a Tropical Ecotone Area. Ecosystems 2019, 22, 266-282.

29. Eigenbrod, F.; Bell, V.A.; Davies, H.N.; Heinemeyer, A.; Armsworth, P.R.; Gaston, K.J. The impact of projected increases in urbanization on ecosystem services. Proc. R. Soc. B Biol. Sci. 2011, 278, 3201-3208. [CrossRef]

30. Costanza, R.; de Groot, R.; Sutton, P.; van der Ploeg, S.; Anderson, S.J.; Kubiszewski, I.; Farber, S.; Turner, R.K. Changes in the global value of ecosystem services. Glob. Environ. Chang. 2014, 26, 152-158. [CrossRef]

31. Costanza, R.; De Groot, R.; Braat, L.; Kubiszewski, I.; Fioramonti, L.; Sutton, P.; Farber, S.; Grasso, M. Twenty years of ecosystem services: How far have we come and how far do we still need to go? Ecosyst. Serv. 2017, 28, 1-16. [CrossRef]

32. Bai, Y.; Wong, C.P.; Jiang, B.; Hughes, A.C.; Wang, M.; Wang, Q. Developing China's Ecological Redline Policy using ecosystem services assessments for land use planning. Nat. Commun. 2018, 9, 1-13. [CrossRef]

33. Zheng, H.; Robinson, B.E.; Liang, Y.-C.; Polasky, S.; Ma, D.-C.; Wang, F.-C.; Ruckelshaus, M.; Ouyang, Z.-Y.; Daily, G.C. Benefits, costs, and livelihood implications of a regional payment for ecosystem service program. Proc. Natl. Acad. Sci. USA 2013, 110, 16681-16686. [CrossRef]

34. Sharp, R.; Tallis, H.T.; Ricketts, T.; Guerry, A.D.; Wood, S.A.; Chaplin-Kramer, R.; Nelson, E.; Ennaanay, D.; Wolny, S.; Olwero, N.; et al. InVEST 3.2.0 User's Guide; The Natural Capital Project, Stanford University, University of Minnesota, The Nature Conservancy, and World Wildlife Fund: Stanford, CA, USA, 2016. [CrossRef]

35. Xu, W.; Xiao, Y.; Zhang, J.; Yang, W.; Zhang, L.; Hull, V.; Wang, Z.; Zheng, H.; Liu, J.; Polasky, S.; et al. Strengthening protected areas for biodiversity and ecosystem services in China. Proc. Natl. Acad. Sci. USA 2017, 114, 201620503. [CrossRef]

36. Mancini, M.S.; Galli, A.; Coscieme, L.; Niccolucci, V.; Lin, D.; Pulselli, F.M.; Bastianoni, S.; Marchettini, N. Exploring ecosystem services assessment through Ecological Footprint accounting. Ecosyst. Serv. 2018, 30, 228-235. [CrossRef]

37. Sun, C.; Wang, Y.; Zou, W. The marine ecosystem services values for China based on the emergy analysis method. Ocean Coast. Manag. 2018, 161, 66-73. [CrossRef]

38. Watanabe, M.D.B.; Ortega, E. Dynamic emergy accounting of water and carbon ecosystem services: A model to simulate the impacts of land-use change. Ecol. Model. 2014, 271, 113-131. [CrossRef]

39. Odum, H.T. Environmental Accounting: Emergy and Environmental Decision-Making; John Wiley Sons, Inc.: Hoboken, NJ, USA, 1996; Volume 370.

40. Pulselli, F.M.; Coscieme, L.; Bastianoni, S. Ecosystem services as a counterpart of emergy flows to ecosystems. Ecol. Model. 2011, 222, 2924-2928. [CrossRef]

41. Coscieme, L.; Pulselli, F.M.; Marchettini, N.; Sutton, P.C.; Anderson, S.; Sweeney, S. Emergy and ecosystem services: A national biogeographical assessment. Ecosyst. Serv. 2014, 7, 152-159. [CrossRef]

42. Grönlund, E.; Fröling, M.; Carlman, I. Donor values in emergy assessment of ecosystem services. Ecol. Model. 2015, 306, 101-105. [CrossRef] 
43. Campbell, D.E.; Lu, H.; Walker, H.A. Relationships among the Energy, Emergy, and Money Flows of the United States from 1900 to 2011. Front. Energy Res. 2014, 2. [CrossRef]

44. Campbell, E.T.; Tilley, D.R. Valuing ecosystem services from Maryland forests using environmental accounting. Ecosyst. Serv. 2014, 7, 141-151. [CrossRef]

45. Lu, H.; Campbell, E.T.; Campbell, D.E.; Wang, C.; Ren, H. Dynamics of ecosystem services provided by subtropical forests in Southeast China during succession as measured by donor and receiver value. Ecosyst. Serv. 2017, 23, 248-258. [CrossRef]

46. Yang, Q.; Liu, G.; Casazza, M.; Campbell, E.T.; Giannetti, B.F.; Brown, M.T. Development of a new framework for non-monetary accounting on ecosystem services valuation. Ecosyst. Serv. 2018, 34, 37-54. [CrossRef]

47. Zhong, S.; Geng, Y.; Qian, Y.; Chen, W.; Pan, H. Analyzing ecosystem services of freshwater lakes and their driving forces: The case of Erhai Lake, China. Environ. Sci. Pollut. Res. 2019, 26, 10219-10229. [CrossRef]

48. Yang, Q.; Liu, G.; Casazza, M.; Hao, Y.; Giannetti, B.F. Emergy-based accounting method for aquatic ecosystem services valuation: A case of China. J. Clean. Prod. 2019. [CrossRef]

49. Pan, H.; Geng, Y.; Tian, X.; Wilson, J.; Chen, W.; Zhong, S.; Song, X. Emergy-based environmental accounting of one mining system. Environ. Sci. Pollut. Res. 2019. [CrossRef]

50. Mellino, S.; Ripa, M.; Zucaro, A.; Ulgiati, S. An emergy-GIS approach to the evaluation of renewable resource flows: A case study of Campania Region, Italy. Ecol. Model. 2014, 271, 103-112. [CrossRef]

51. Pulselli, R.M. Integrating emergy evaluation and geographic information systems for monitoring resource use in the Abruzzo region (Italy). J. Environ. Manag. 2010, 91, 2349-2357. [CrossRef]

52. Huang, S.L.; Chen, Y.H.; Kuo, F.Y.; Wang, S.H. Emergy-based evaluation of peri-urban ecosystem services. Ecol. Complex. 2011, 8, 38-50. [CrossRef]

53. OECD. Indicators to Measure Decoupling of Environmental Pressure from Economic Growth; OECD Environment Program: Paris, France, 2002.

54. Tapio, P. Towards a theory of decoupling: Degrees of decoupling in the EU and the case of road traffic in Finland between 1970 and 2001. Transp. Policy 2005, 12, 137-151. [CrossRef]

55. Zhao, X.; Zhang, X.; Li, N.; Shao, S.; Geng, Y. Decoupling economic growth from carbon dioxide emissions in China: A sectoral factor decomposition analysis. J. Clean. Prod. 2017. [CrossRef]

56. Lin, B.; Wang, M. Possibilities of decoupling for China's energy consumption from economic growth: A temporal-spatial analysis. Energy 2019. [CrossRef]

57. Chen, J.; Wang, P.; Cui, L.; Huang, S.; Song, M. Decomposition and decoupling analysis of $\mathrm{CO}_{2}$ emissions in OECD. Appl. Energy 2018. [CrossRef]

58. Li, Y.N.; Cai, M.; Wu, K.; Wei, J. Decoupling analysis of carbon emission from construction land in Shanghai. J. Clean. Prod. 2019. [CrossRef]

59. Lu, Y.; Geng, Y.; Qian, Y.; Han, W.; McDowall, W.; Bleischwitz, R. Changes of human time and land use pattern in one mega city's urban metabolism: A multi-scale integrated analysis of Shanghai. J. Clean. Prod. 2016, 133, 391-401. [CrossRef]

60. Pan, H.; Zhuang, M.; Geng, Y.; Wu, F.; Dong, H. Emergy-based ecological footprint analysis for a mega-city: The dynamic changes of Shanghai. J. Clean. Prod. 2019, 210, 552-562. [CrossRef]

61. Yue, W.; Fan, P.; Wei, Y.D.; Qi, J. Economic development, urban expansion, and sustainable development in Shanghai. Stoch. Environ. Res. Risk Assess. 2014, 28, 783-799. [CrossRef]

62. Shanghai Statistical Yearbook; China Statistics Press: Beijing, China, 2011. Available online: http://www.stats. gov.cn/tjsj/ndsj/2007/indexee.htm (accessed on 8 September 2019).

63. Liu, G.; Yang, Z. Emergy Theory and Practice: Ecological Environental mAccounting and Urban Green Management; Science Press: Beijing, China, 2018. (in Chinese)

64. Zhang, W.; Sun, N.; Han, Y. Assessment of atmospheric purification function of urban forest ecosystem in Shanghai. J. Chin. Urban For. 2018, 16, 482-494.

65. Teng, H. Assimilating Multi-source Data Model and Map Potential Soil Loss in China. Ph.D. Thesis, Zhejiang University, Hangzhou, China, 2017.

66. Brown, M.T.; Ulgiati, S. Emergy assessment of global renewable sources. Ecol. Model. 2016, 339, 148-156. [CrossRef]

67. Geng, Y.; Sarkis, J.; Ulgiati, S.; Zhang, P. Measuring China's circular economy. Science 2013, 340, 1526-1527. [CrossRef] 
68. Wu, R.; Dai, H.; Geng, Y.; Xie, Y.; Masui, T.; Liu, Z.; Qian, Y. Economic Impacts from PM ${ }_{2.5}$ Pollution-Related Health Effects: A Case Study in Shanghai. Environ. Sci. Technol. 2017, 51, 5035-5042. [CrossRef]

69. Jia, X.; Fu, B.; Feng, X.; Hou, G.; Liu, Y.; Wang, X. The tradeoff and synergy between ecosystem services in the Grain-for-Green areas in Northern Shaanxi, China. Ecol. Indic. 2014, 43, 103-113. [CrossRef]

70. Pan, H.; Zhang, X.; Wu, J.; Zhang, Y.; Lin, L.; Yang, G.; Deng, S.; Li, L.; Yu, X.; Qi, H.; et al. Sustainability evaluation of a steel production system in China based on emergy. J. Clean. Prod. 2016, 112, 1498-1509. [CrossRef]

71. Zhang, X.; Jiang, W.; Deng, S.; Peng, K. Emergy evaluation of the sustainability of Chinese steel production during 1998-2004. J. Clean. Prod. 2009, 17, 1030-1038. [CrossRef]

72. World Health Organization (WHO). Metrics: Disability Adjusted Life Year (DALY). 2013. Available online: http://www.who.int/healthinfo/global_burden_disease/metrics_daly/en/(accessed on 6 September 2019).

73. Goedkoop, M.; Spriensma, R. The Eco-indicator 99: A Damage Oriented Method for Life Cycle Impact Assessment: Methodology Report; PRé Sustainability: Amersfoort, The Netherlands, 2000.

74. State Forestry Administration of the People's Republic of China. Specifications for Assessment of Wetland Ecosystem Services; (LY/T2899-2017); State Forestry Administration of the People's Republic of China: Beijing, China, 2017.

75. Rejani, R.; Rao, K.V.; Osman, M.; Srinivasa Rao, C.; Reddy, K.S.; Chary, G.R.; Pushpanjali, S.J. Spatial and temporal estimation of soil loss for the sustainable management of a wet semi-arid watershed cluster. Environ. Monit. Assess 2016. [CrossRef]

76. Kremen, C.; Merenlender, A.M. Landscapes that work for biodiversity and people. Science 2018, 362. [CrossRef]

77. Hector, A.; Inchausti, P.; Lavorel, S.; Lawton, J.H.; Lodge, D.M.; Loreau, M.; Naeem, S.; Schmid, B.; Setälä, H.; Symstad, A.J.; et al. Effects of Biodiversity on Ecosystem Functioning: A Consensus of Current Knowledge. Ecol. Monogr. 2005, 75, 3-35.

78. Campbell, E.T.; Tilley, D.R. Relationships between renewable emergy storage or flow and biodiversity: A modeling investigation. Ecol. Model. 2016, 340, 134-148. [CrossRef]

79. Zheng, H.; Wang, L.; Wu, T. Coordinating ecosystem service trade-offs to achieve win-win outcomes: A review of the approaches. J. Environ. Sci. 2019, 82. [CrossRef]

80. Qiu, J.; Turner, M.G. Spatial interactions among ecosystem services in an urbanizing agricultural watershed. Proc. Natl. Acad. Sci. USA 2013, 110, 12149-12154. [CrossRef]

81. Zhang, G.; Chen, Y.; Liu, Y.; Zhang, Y.; Liu, Y.; Zhang, Y. On the spatial relationship between ecosystem services and urbanization: A case study in Wuhan, China. Sci. Total Environ. 2018, 637-638, 780-790. [CrossRef]

82. Keeler, B.L.; Hamel, P.; McPhearson, T.; Hamann, M.H.; Donahue, M.L.; Meza Prado, K.A.; Arkema, K.K.; Bratman, G.N.; Brauman, K.A.; Finlay, J.C.; et al. Social-ecological and technological factors moderate the value of urban nature. Nat. Sustain. 2019, 2, 29-38. [CrossRef]

83. Endreny, T.A. Strategically growing the urban forest will improve our world. Nat. Commun. 2018. [CrossRef]

84. Wang, K.C.; Dickinson, R.E.; Wild, M.; Liang, S. Atmospheric impacts on climatic variability of surface incident solar radiation. Atmos. Chem. Phys. 2012, 12, 9581-9592. [CrossRef]

85. Sun, P. Land Use Change Analysis and Modeling Prediction in Shanghai Coastal Zone in Recent 30 Years; University of Chinese Academy of Sciences: Beijing, China, 2017.

Publisher's Note: MDPI stays neutral with regard to jurisdictional claims in published maps and institutional affiliations.

(C) 2020 by the authors. Licensee MDPI, Basel, Switzerland. This article is an open access article distributed under the terms and conditions of the Creative Commons Attribution (CC BY) license (http://creativecommons.org/licenses/by/4.0/). 